\title{
İnovasyonun Firma Performansı Üzerine Etkisi: Bistte İmalat Sektöründe Faaliyet Gösteren Firmalar Üzerine Bir İnceleme *
}

\section{Effect of Innovation on Firm Performance: A Study on Manufacturing Companies in Bist}

\author{
Yakup Aslan, ${ }^{\mathrm{a}, * *}$ Mehmet Aygün ${ }^{\mathrm{b}}$ \\ ${ }^{a}$ Dr. Öğr. Üyesi, Muş Alparslan Üniversitesi, Sağlık Bilimleri Fakültesi, Sağlık Yönetimi Bölümü, 49000, Muş/Türkiye. \\ ORCID: 0000-0001-9833-8840 \\ ${ }^{\text {b }}$ Prof. Dr., İktisadi ve İdari Bilimler Fakültesi, İşletme Bölümü, 65000, Van/Türkiye. \\ ORCID: 0000-0003-2782-3093
}

\begin{tabular}{l} 
MAKALE BİLGİṠ̇ \\
Makale Geçmişi: \\
Başvuru tarihi: 01 Ocak 2019 \\
Düzeltme tarihi: 18 Nisan 2019 \\
Kabul tarihi: 23 Nisan 2019 \\
\hline Anahtar Kelimeler: \\
İnovasyon \\
Firma Performans1 \\
Performans \\
Yapısal Eşitlik Modellemesi \\
A R T I C L E I N F O \\
Firm Performance \\
Performance \\
Structural Equation Modeling \\
Received 01 January 2019 \\
Received in revised form 18 April 2019 \\
Accepted 23 April 2019 \\
\hline Keywords: \\
Innovation \\
Arto
\end{tabular}

\section{ÖZ}

Firmalar değişen müşteri beklentilerini takip etmekte güçlük çekmekte ve küreselleşmenin doğal çıktısı olan amansız rekabetle baş etmenin yollarını aramaktadırlar. Çevresel faktörlerin estirdiği değişim rüzgarları, Türk sermaye piyasasında faaliyet gösteren firmaları da doğrudan etkilemektedir. Firmaların hayatlarını sürdürebilmeleri, sürdürülebilir ve avantajlı rekabet üstünlüğünü sağlayarak firma performanslarını en üst seviyeye çıkaracak faaliyetlerin peşinde koşmaları kaçınılmaz hale gelmiştir. Bunun içinde inovasyon faaliyetleri gibi enstrümanlara duyulan ihtiyacın her geçen gün artıs trendinde olduğu ifade edilebilir.. Borsa İstanbul'da İmalat sanayiinde faaliyet gösteren 135 firma üzerine çalışma yapılmıştır. Çalışmada anket yöntemi kullanılmışırı. Verilerin analizinde SPSS versiyon 25 paket programıyla betimsel istatistiklerin yanında açıklayıcı faktör analizinden yararlanılmıștır. LISREL 9.1 paket programıyla doğrulayıcı faktör analizi ve yapısal eşitlik modellemesi ile kurulan yol analizinden yararlanılarak hipotezler test edilmiştir.

\section{A B S T R AC T}

Firms are having difficulty keeping up with changing customer expectations and seeking ways to cope with the relentless competition of globalization. The changing winds exerted by environmental factors also directly affect firms operating in the Turkish capital market. It has become inevitable for companies to pursue activities that can lead their lives, maximize firm performance by providing sustainable and advantageous competitive advantage. The stock exchange has been working on 135 companies operating in the manufacturing industry in Istanbul. Questionnaire method was used in the study. In the analysis of the data, explanatory factor analysis was utilized besides descriptive statistics with the SPSS version 25-package program. LISREL 9.1 has benefited from the path analysis established by confirmatory factor analysis and structural equation modeling with the package program.

\section{Giriş}

Yenilikçilik, yeni pazarlar keşfetmek, sahip olunan pazar payını arttırmak ve şirkete rekabet avantajı sağlamak gibi büyüme hedeflerinin temel araçlarından biridir. Küresel pazardaki artan rekabetin, buna bağlı olarak da değişen teknolojilerin oluşturduğu yeni dünya düzeninde, mevcut ürünlerin ve hizmetlerin katma değeri düşmeye mahkum olduğundan, firmalar yenilikçiliğin önemini kavramaya başlamışlardır. Bu nedenle, yenilikler, daha üretken üretim süreçleri uygulamak, piyasada daha iyi performans göstermek, müşterilerin algısında olumlu bir algı bırakmak

* Bu çalışma birinci yazarın 2018 yılında Prof. Dr. Mehmet AYGÜN danışmanlığında Van Yüzüncü Yıl Üniversitesi Sosyal Bilimler Enstitüsü İşletme Anabilim Dalı’nda yürüttüğ̈̈ “İnovasyonun Firma Performansı Üzerine Etkisi: Türk Sermaye Piyasası Üzerine Bir İnceleme” başlıklı doktora tezinden türetilmiştir.

** Sorumlu yazar/Corresponding author

e-posta: y.aslan@alparslan.edu.tr

e-ISSN: 2149-4622. (C) 2013-2018 Muş Alparslan Üniversitesi. TÜBİTAK ULAKBİM DergiPark ev sahipliğinde. Her hakkı saklıdır. 
ve sonuçta sürdürülebilir rekabet avantajı elde etmek gibi çeşitli nedenlerle kurumsal stratejilerin vazgeçilmez bir bileşenini oluşturmaktadır (Gunday vd., 2011).

Özellikle son yirmi yılda yenilikçilik, pratik ilgisi nedeniyle performans etkilerini tanımlamak, kategorilere ayırmak ve araştırmak isteyen araştırmacılar için cazip bir çalışma alanı haline gelmiştir. Bu bağlamda araştırmamızın en nihai amacı, yenilikçiliğin temel taşları arasında olduğu birçok çalışma ile ortaya konulan yenilikçiliğin, firma performansına, işletme dinamiklerine ne ölçüde etkide bulunduğu konusunu ele almaktır. Özellikle Türk sermaye piyasasında faaliyet gösteren firmalara inovasyonperformans ilişkisinin etkilerini ortaya koyarak yeni bakış açıları kazandırmaktır. 1980'lerden sonra özellikle zorlaşan küresel rekabet, gerek dünyada gerekse Türkiye'de şirketleri iş stratejilerine, özellikle yeniliklere odaklanmaya yöneltmiştir. Günümüzde, zorlu küresel rekabete bağlı olarak, hem bireysel yatırımcılar hem de şirketler, yenilik stratejilerini ve girişimci yeteneklerini, rekabet avantajı kazanma amacı ile değerlendirmeye ve uygulamaya başladıkları görülmektedir. Aslında yenilikçiliğin başlıca nedeni, firmaların artan iş performansı elde etme arzusu ve rekabet gücü artmasıdır. Şirketler, yeniliklere verdikleri önem derecesine göre ek rekabet avantajı ve pazar payı sağlayabilir. $\mathrm{Bu}$ da şirketlerin pazarda görmek istedikleri saygıyı kazanmaları hususuna katkıda bulunarak mevcut pazar paylarının doğal olarak arttırılmasına olanak sağlamaktadır.

\section{2. İnovasyon}

\section{1. İnovasyon Nedir?}

İnovasyon (innovation) kelime olarak, "yenilemek veya değiştirmek" anlamında kullanılan Latince kökenli "innovatus" kelimesinden türemiştir (Elçi, 2006: 1). İnovasyon çok uzun süredir araştırmacıların üzerinde ilgiyle çalıştığı bir konudur. Türkiye'de ise inovasyona ilgi 2000'li yıllarda artmış, bu ilgi alan yazındaki çalışmalardaki artışa yansımıştır. Bu denli popüler bir kavram olan inovasyon, ilk defa Joseph Schumpeter tarafindan dillendirilmiş, kalkınmada itici güç olabileceği ifade edilmiştir. Schumpeter, 1911 yılında kaleme aldığı, 1934 yılında çevirisi yapılan "Ekonomik Gelişme Teorisi" adlı eserinde ilk kez yenilikçilik kavramını dile getirmiştir. Bahsi geçen eserde, inovasyonu, temel de müşteriler tarafından henüz bilinir olmayan bir ürünü ya da mevcutta olan üründe değişiklik yapmak suretiyle ilave özellikler kazandırmak olarak ele almıştır. Bunu da üretim organizasyonunda yenilik, pazar keşfinde yenilik, hammaddelerin yahut yarı mamullerin edinilmesinde hâlihazırda kullanılan süreçten farklı bir süreç inşa ederek kaynağa erişimin rahatlatılması gibi seçeneklerle sağlanacağını vurgulamıştır (Elçi vd., 2008: 25). İnovasyon; faklı bir ürün veya eldeki ürünün kalitesini geliştirme, üretimde yeni bir süreç, yeni bir pazar keşfetme, üretim girdilerinde yeni bakış açıları geliştirme ve üretimde organizasyonu zenginleştirmek gibi süreçleri içine alan bir kavramdır (Schumpeter, 1983). İnovasyon temelde iki boyutlu bir kavram ve birbirini tamamlama faaliyetidir. İnovasyon bir yönüyle, ekonomik olarak yeni bir ürünü veya süreci piyasanın gerçekten ihtiyaç duyacağı şekilde dizayn ederken, öte yandan ulaşılması zor olmayan teknik bilgiler yardımıyla ve de, özgün çalışmalar neticesinde yeni bilimsel ve teknolojik bilgilerinin gerekliliğini vurgular (Freeman vd., 1997). İnovasyon tanımı hususunda OECD ile Eurostat'ın beraber yayınladığı ve uluslararası otoritelerce değer gören Oslo Kılavuzu referans teşkil etmektedir. Kılavuza göre yenilik (inovasyon) : "yeni veya kayda değer manada üründeki değişiklikleri veya süreçteki faklılıkları; farklı bir pazarlama anlayışının veya işin gerçekleştirilmesinde, işyeri örgütlenmesinde ya da diş çevreyle olan ilişkilerin yeni bir organizasyon yaklaşımıyla temelinin atılmasıdır (OECD, 2005).

\section{2. İnovasyonun Önemi}

Yasadığımız çağda, çevresel değişimdeki çeşitlilik ve çevresel düzeydeki karmaşık durum geçmiş dönemlerle mukayese edilemeyecek kadar ileri düzeydedir. Bir organizasyon yapısını değiştirebilmenin yöntemlerinden birisi inovasyondur. İnovasyon, işletmelerin çevresel değişikliklere dönük tasarladıkları bir karşılık veya bu değişikliklerde bizzat rol aldıkları bir süreçtir (Damanpour, 1992: 377). İnovasyonun firmalara sunduğu avantajlar arasında; verimlilik düzeyinde artış, sürdürülebilir rekabette üstünlük sağlanması, ödemeler dengesizliğinde yaşanan sorunlara çare olması, toplumda sosyal sorumluluk bilincinin oluşturulması ve geliştirilmesi, sadık müşteri yelpazesinin genişletilmesi, kurumsallaşma ve markalaşmayı sağlamak suretiyle firmaları Ar-Ge'nin vadettiği kaliteli çıktılara yöneltmesi gibi birçok husus sıralanabilir. Günümüzde rekabetin yaşanmadığı sektör yok denecek kadar azdır. Böyle bir iklimde sürdürülebilir rekabetin en etkin enstrümanının yenilikçi bakış açısıyla oluşturulan stratejiler olduğu görülmektedir. Yüksek teknolojiden beslenen inovasyon odaklı ekonomilerin, büyümede ve dolayısıyla ödemeler dengesine anlamlı düzeyde katkı sunmaktadır. Örgütleri rekabete ve geleceğe bağlayan zincir halkaları şeklinde düşünülebilecek olan inovasyon (Wong ve Chin, 2007: 1290), rekabetteki artış, teknolojideki hızlı ve radikal dönüşümler ve müşteri beklentilerindeki farklılıklardan dolayı daha pahalı, risk barındıran ve karmaşık bir boyuta evrilmiştir (Cavusgil vd., 2003: 6-7). Lakin yaşanmakta olan bilgi ekonomisinde örgütsel adaptasyon ve yenilenmenin (Nohria ve Gulati, 1996: 1245), ve sürdürülebilir rekabet avantajının tek kaynağı da inovasyondur (Chen ve Ho, 2002: 46), (Sutherland vd., 2002: 33)

\subsection{Performans ve Firma Performans1}

Konuyla ilgili literatürde işletme ve işletmeyle ilgili birçok alanda performans ve firma performansı kavramlarının ele alındığ 1 görülmektedir. Esasında performans kavramı işletmelerin neredeydik, nereye geldik sorularına verdikleri cevaplar bütünüdür. Konuyla ilgili mevcut yazın incelendiğinde, işletme ve işletmeyle ilgili birçok disiplinin ilgi alanı içerisinde yer alan "performans" kavramına ilişkin çok sayıda çalışma yapıllmış olduğu görülmektedir.

Ayrıca gerçekleştirilen korelasyon analizi neticeleri, inovasyon ile firma performansının farklı boyutları arasında da anlamlı ve pozitif yönlü ilişkiler bulunduğunu gün yüzüne çıkarmaktadır. İnovasyon ile firma performansı özelinde gözlemlenen bu ilişki (Atalay vd., 2013), (Gunday vd., 2011), (Biçkes, 2011), (Eren vd., 2010), (Grawe vd., 2009), (Matzler vd., 2008), (Zehir ve Özşahin, 2007), (Shergill ve Nargundkar, 2005) ve (Cainelli vd., 2004) gibi pek çok araştırma sonuçlarıyla desteklenmektedir. $\mathrm{Bu}$ bağlamda, 
inovasyon ölçümünde yüksek skor üreten firmalar, inovasyon ölçümünde düşük skor üreten firmalara nispetle daha üst düzey performans ürettikleri rahatlıkla ifade edilebilir.

Teorik ve uygulamalı araştırmalarda yaygın olarak kullanılan bir değişken olmasına rağmen, "performans" kavramı belirsizliğini koruyan, ölçülmesi zor olan ve etrafında fikir birliğine varılmış bir tanımı bulunmayan bir kavramdır (E. W. Rogers ve Wright, 1998: 316). Türk Dil Kurumu (2014) performans kavramının Türkçe karşılığı olarak "başarım" kelimesini tanımlamakta ve "yapılan iş, uygulama, icraat, herhangi bir olayı veya durumu başarma isteği ve gücü" şeklinde açıklamaktadır. Firma performansı, belli düzeylerde değerlendirilmesi gereken bir yapıdır. İlk düzey finansal performans, ikinci düzey operasyonel performans ve son düzeyde örgütsel etkinlik performansı olmak üzere üç temel düzeyde ele alınan çok boyutu bir arada barındıran bir yapıdır (Hart ve Banbury, 1994: 258). Ulaşılan kârlılık düzeyinin bir göstergesi olan finansal performans, yatırımdaki kârlılık (return on assets-ROA), özsermayedeki kârlılık (return on equity-ROE) ve satışlardaki kârlılık (return on sales-ROS) şeklinde ana omurgası muhasebe temelli ölçütler ile değerlendirilmektedir. Operasyonel performans göstergeleri olarak, yatırım geri dönüş oranı, kârlılık artışı, satış hacmi, pazar payı (Green ve Inman, 2007: 1010), çeşitlendirme, ürün geliştirme vb. gibi pazar temelli ölçütler kullanılmaktadır (Hart ve Banbury, 1994: 258). Örgütsel etkinlik ise bir işletmenin kar, verimlilik, çalışan tatmini, finansal yapıda sürdürülebilir başarı ve benzeri gibi karmaşık amaçlara ulaşma, değişen çevre koşullarına ayak uydurabilme ve varlığını idame ettirebilme yeteneğidir (Chung ve Megginson, 1981: 506). Performans yönetiminin temel amacı, işletme etkinliğini ve firmanın katma değer oluşturma serüvenine katkı sunabilecek, sürekli iyileşmeyi sağlayacak tüm tarafların sorumluluk almaktan kaçınmayacağı bir kültür oluşturmaktır (Helvacı, 2002: 156).

\subsection{Bistte Faaliyet Gösteren Firmalar}

$\mathrm{Bu}$ çalışmada, inovasyon ve firma performansı arasındaki ilişkiler, Borsa İstanbul (BİST)'da sektörel boyutta imalat sanayiinde faaliyet gösteren 182 firma temel veri paketi olarak ele alınmıştır. Esasında BİST' te faaliyet gösteren 513 firma vardır. $\mathrm{Bu}$ şirketlerin sektörel düzeydeki başlıkları şunlardır;

\footnotetext{
- Tarım, Orman ve Balıkçılık,

- $\quad$ Madencilik,

- $\quad$ Elektrik, Gaz ve Su,

- $\quad$ İnşaat ve Bayındırlık,

- Toptan ve Perakende Ticaret Otel ve Lokantalar,

- Ulaştırma Haberleşme ve Depolama,

- Mali Kuruluşlar,

- $\quad$ Eğitim, Sağlık, Spor ve Diğer Sosyal Hizmetler,

- Kiralama ve İş Faaliyetleri,

- Teknoloji, Mesleki ve Bilimsel Teknik Faaliyetler,

- $\quad$ İdari ve Destek Hizmet Faaliyetleri,
}

\section{- $\quad$ Gayri Menkul Faaliyetleri \\ - İmalat Sanayii'dir.}

\section{Araştırmanın Problemi ve Amacı}

\subsection{Araştırmanın Problemi}

Belli amaçları yerine getirebilmek ve işletmenin sürekliliği esası ile sürekli bir yaşam döngüsü var kabul edilen işletmeler varlıklarını sürdürebilmenin yollarını aramaktadırlar. $\mathrm{Bu}$ sayede faaliyetlerini sürdürürken performanslarını da arttırarak, rekabette doğru pozisyon alabilmenin yolunu aramaktadırlar. Bunun için de rekabette kendilerine avantaj sağlayacak enstrümanlara ihtiyaç duymaktadırlar. İnovasyon da bu enstrümanlardan biri olarak kabul edilmektedir. Türk sermaye sisteminde inovasyonun bahsedilen avantajları sağlayıp sağlamadığını gözlemleyerek, firmaların performansı üzerindeki etkilerini ortaya koymak çalışmanın konusunu oluşturmaktadır. Bu bakış açısıyla çalışmanın konusu; inovasyon ve firma performansı arasındaki ilişki üzerine odaklanacak ve bu iki değişken arasındaki ilişki Türk sermaye yapısının kalbi olarak nitelendirilen Borsa İstanbul(BİST)'da imalat sektöründe faaliyet gösteren 182 firma referans kabul edilerek elde edilen veriler ışığında analizler yapılacaktır.

\subsection{Araştırmanın Amacı}

İnovasyon ile firma performansı arasındaki etkileşimi ele alan birçok çalışmanın literatürde yerini aldığı görülmektedir. $\mathrm{Bu}$ bağlamda ülkemiz sermaye yapısının ülkeler klasmanında gelişmekte olan ülkeler kategorisinde yer aldığı bilinmektedir. Araştırmanın sunacağı temel amaçlarından biri gelişen ülkeler ligine yükselmek için ihtiyaç duyulan katma değere katkı sunacağıdır. Bu anlamda çalışmanın literatürdeki boşluğu doldurmada önemli bir rol üstleneceği düşünülmektedir. Ayrıca araştırma sonuçları, firma performansının artırılması noktasında inovasyonun rolünü kanıtlayacak ve bu bağlamda firma yöneticileri başta olmak üzere tüm işletme paydaşlarına bu konuda fikir verebilir. Araştırma sonuçlarının etkileri firmalarla sınırlı kalmayacaktır. BIST' de yatırım yapmak isteyen yatırımcılara alacakları kararlarda yol gösterecektir. Bu sayede yatırım yapılmak istenen firmanın inovasyona olan bakış açısı önemli değişkenlerden biri olarak yerini alabileceği öngörülebilir.

$\mathrm{Bu}$ ifadeler odağında çalışmanın nihai amacı; inovasyon ile firma performansı arasındaki ilişki düzeyini tespit ederek, bu alanlarda bilgi sahibi olmak isteyen tüm taraflara ihtiyaç duyulan bilginin sunulabilmesidir.

\section{Yöntem}

\subsection{Araştırma Modeli ve Hipotezler}

Araştırmada yapısal eşitlik modellemesiyle inovasyonun firma performansına etkileşimini gözlemleyebilmek için yol analizi modeli tercih edilmiştir.

- H1: Ürün İnovasyonu firma performansı üzerinde pozitif etkiye sahiptir. 
- $\quad$ H2: Süreç İnovasyonu firma performansı üzerinde pozitif etkiye sahiptir.

- H3: Pazarlama İnovasyonu firma performansı üzerinde pozitif etkiye sahiptir.

- H4: Organizasyonel İnovasyon firma performansı üzerinde pozitif etkiye sahiptir.

\subsection{Evren ve Örneklem}

Evren (population), araştırma bulgularının genellenerek içerisinden araştırma örnekleminin seçilerek oluşturulan büyük gruba denir (Gürbüz ve Şahin, 2016: 127). Örneklem, evrenden seçilmesi gereken, araştırma problemini çözecek verilerin ulaşıldığı, evreni temsil edebilme kabiliyetine sahip evrenin bir alt parçasıdır (Yazıcıoğlu ve Erdoğan, 2014: 32). Örnekleme (sampling) ise elde bulunan evrenden örnek seçme olayıdır (Arıkan, 2000: 119).

Araştırmanın evrenini, Türk Sermaye Sistemi açısından önemi büyük olan Borsa İstanbul'da faaliyet gösteren 513 firma oluşturmaktadır. Anketin değerlendirilmesi ve tatbikinde, bilgi toplanılmak istenen topluluk hakkında oluşan tüm birimlerin gözlenmesi (Serper ve Aytaç, 2000: 1) biçiminde ifade edilen "tam sayım yöntemi" referans alınmıştır.

Örneklem perspektifinde olan firmaların iletişim bilgileri Kamuyu Aydinlatma Platformu(KAP)'un web adresinden sağlanmıştır. KAP'ın sitesinde Şirketler sekmesinin alt başlığı olan BIST şirketleri olarak sunulan 513 firma bilginine ulaşılmıştır. Sektörel bazlı verilen listelerde sektörlerde faaliyet gösteren firmaların sayılarının birbirinden farklı olması, firma büyüklükleri vb. sebeplerinden dolayı örneklemin doğru rasyonel sonuçlar sunabilmesi gerekçesinden ötürü 513 firmadan İmalat Sanayiinde faaliyet gösteren 182 firma belirlenmiştir.

\subsection{Veri Toplama Aracı}

Çalışmamızın odağını, inovasyonun firma performansı üzerindeki etkilerini ölçmek oluşturmaktadır. Ölçümün Türk sermaye sistemi özelinde ele alınmış olması çalışmanın hassasiyet düzeyine işaret etmektedir. Çalışmada seçilen anket ölçeğinin olabildiği kadar sade, anlaşılır olmasına dikkat edilmiştir. İnovasyon ile yapılan çalışmalar dikkate alındığında tamamına yakınının oluşturdukları ölçekte OECD tarafindan yayınlanan 'Oslo Kılavuzu: Yenilik Verilerinin Toplanması ve Yorumlanması İçin İlkeler' kaynağının referans alındığı görülmektedir. Bu bağlamda anket ölçeğinin çalışmamızın amacına katkı sunması ve komple bir değerlendirme yapılabilmesi için literatürde bahsi geçen kılavuzdan yararlanılan anket ölçeği taraması yapılmıştır.

Tarama sonucunda, (Gunday vd., 2011: 672-674) çalışmalarında kullandıkları ölçeğin çalışmamızın içerik ve amacına en uygun ölçek olduğuna karar verilmiştir. Anket ölçeği; 2 bölüm ve 8 başlıktan oluşmaktadır. Katılımcılardan her bir ifade için katılım düzeylerini belirlemek adına beş noktalı likert tipi ölçek üzerinde ifade etmeleri istenerek katılımcılara sunulmuştur. Bu başlıklar özetle;
Ürün inovasyonu ölçümünü (5 ifade) ölçmek için, 'Aşağıdaki faaliyet türleri ile ilgili olarak son üç yıl içinde ürün yenilikleri kuruluşunuzda ne sıklıkla uygulanmıştır?' Sorusunu, (1=Uygulanmadı, 2=Ulusal Pazarlardan Taklit Edildi, 3=Uluslararası Pazarlardan Taklit Edildi, 4=Mevcut Ürün Geliştirildi, 5=Orijinal Yeni Bir Ürün Geliştirildi.) işaretlemeleri istenmiştir.

Süreç İnovasyonu ölçümünü ( 5 ifade) ölçmek için, 'Son üç yılda organizasyonunuzda ne tür süreç yenilikleri uyguland1?' Sorusunu; (1=Uygulanmad1, 2=Ulusal Pazarlardan Taklit Edildi, 3=Uluslararası Pazarlardan Taklit Edildi, 4=Mevcut Süreç Geliştirildi, 5=Orijinal Yeni Bir Süreç Geliştirildi) işaretlemeleri istenmiştir.

Pazarlama inovasyonu ölçümünü (5 ifade) değerlendirmek için, 'Son üç yılda organizasyonunuzda ne tür pazarlama yenilikleri uygulandı?' Sorusunu; (1=Uygulanmadı, 2= Ulusal Pazarlardan Taklit Edildi, 3=Uluslararası Pazarlardan Taklit Edildi, 4=Mevcut Ürün Geliştirildi, 5=Orijinal Yeni Bir Pazar Geliştirildi) işaretlemeleri istenmiştir.

Organizasyonel inovasyon ölçümünü $\quad(9$ ifade $)$ değerlendirebilmek için, 'Son üç yılda organizasyonunuzda ne tür organizasyonel yenilikler uygulandı?' Sorusunu, (1=Uygulanmadı, 2=Ulusal Pazarlardan Taklit Edildi, 3= Uluslararas1 Pazarlardan Taklit Edildi, $4=$ Mevcut Organizasyon Geliştirildi, 5=Orijinal Yeni Organizasyon Geliştirildi.) işaretlemeleri istendi.

İnovatif performans ölçümünü (7 İfade) değerlendirmek için, 'Geçmiş yıllara kıyasla son üç yıl içinde kuruluşunuzdaki aşağıdaki yenilikçi performans öğelerinin başarı düzeyini nasıl değerlendiriyorsunuz?' Sorusunu, (1=Çok Başarısız, 2=Başarısız, 3=Orta, 4=Başarılı, 5=Çok Başarıl1.) verilen beş sayılık ölçekler arasından uygun olanı işaretlemeleri istenmiştir. $\mathrm{Bu}$ beş sayılık ölçekler, ürün performans ölçümünde, Pazar performans ölçümünde ve finansal performans ölçümünde aynen kullanıldığ 1 için tekrar ifade edilmeyecektir.

Ürün performans ölçümünü (4 ifade) değerlendirmek için, 'Organizasyonunuzdaki son üç yılda önceki yıllara kıyasla aşağıdaki üretim performans öğelerinin başarı seviyesini nasıl değerlendirirsiniz?' Sorusunu, verilen beş sayılık ölçekler arasından uygun olanı işaretlemeleri istenmiştir.

Pazar performans ölçümünü (3 ifade) değerlendirmek için, 'Geçen yıllara kıyasla son üç yıl içinde kuruluşunuzdaki aşağıdaki pazar performansı kalemlerinin başarı seviyesini nasıl değerlendirirsiniz?' Sorusunu, verilen beş sayılık ölçekler arasından uygun olanı işaretlemeleri istenmiştir. Ve son olarak;

Finansal performans ölçümünü (4 ifade) değerlendirmek için, 'Son üç yıl içinde önceki yıllarla karşılaştırıldığında kuruluşunuzdaki aşağıdaki finansal performans öğelerinin başarı düzeyini nasıl değerlendiriyorsunuz?' Sorusunu, verilen beş sayılık ölçekler arasından uygun olanı işaretlemeleri olmak üzere, 8 boyut ve toplam 42 ifadeden oluşmaktadır. 


\subsection{Araştırma Bulguları ve Yorumu}

$\mathrm{Bu}$ kısımda yukarıda ifade edilen hususları genel çerçeve olarak değerlendirdiğimizde çalışmanın inovasyon ölçeğinin literatürün beklediği düzeylere erişip erişmediği sonuçlarıyla birlikte verilmiștir. Bu sayede çalıșma için düșünülen en uygun modelin yapısal eşitlik modellemesi özelinde doğru yorumlanabilmesine olanak sağlamıştır. Elde edilen sonuçlar doğrulayıcı faktör analizi ile teyit edilerek modelin alt yapısını oluşturan hipotezlerin desteklenip desteklenmediği gözler önüne serilmiş̧ir.

Tablo 1. İnovasyon Ölçeğine Dair Açıklayıcı Faktör Analizi ve Güvenilirlik Analizi Sonuçları

\begin{tabular}{|c|c|c|c|c|}
\hline İfadeler & $\begin{array}{c}\text { Öğg } \\
\text { Silindiğinde } \\
\text { Ölçek } \\
\text { Ortalmas1 }\end{array}$ & $\begin{array}{c}\text { Öğe } \\
\text { Silindiğinde } \\
\text { Varyans } \\
\text { Ortalamas1 }\end{array}$ & $\begin{array}{l}\text { Düzeltilmiş } \\
\text { Madde- } \\
\text { Toplam } \\
\text { Korelasyon }\end{array}$ & $\begin{array}{c}\text { Öğge } \\
\text { Silindiğinde } \\
\text { Cronbach's } \\
\text { Alpha }\end{array}$ \\
\hline $\begin{array}{l}\text { 1.Mevcut ürünlerin imalat kalitesindeki bileşenlerinin ve } \\
\text { malzemelerinin arttırılması }\end{array}$ & 86,27 & 429,66 & 0,68 & 0,98 \\
\hline $\begin{array}{l}\text { 2.Mevcut ürünlerin bileşenleri ve malzemelerindeki üretim } \\
\text { maliyetinin düşürülmesi }\end{array}$ & 86,19 & 431,08 & 0,71 & 0,98 \\
\hline $\begin{array}{l}\text { 3.Müşteriler için geliştirilmiş kullanım kolaylığına ve mevcut } \\
\text { müşteri memnuniyetine yol açan mevcut ürünlerin yeniden } \\
\text { geliştirilmesi }\end{array}$ & 86,09 & 432,86 & 0,74 & 0,97 \\
\hline $\begin{array}{l}\text { 4.Mevcut olanlardan farklı teknik özelliklere ve işlevlere sahip yeni } \\
\text { ürünler geliştirilmesi }\end{array}$ & 86,17 & 429,59 & 0,75 & 0,97 \\
\hline $\begin{array}{l}\text { 5.Mevcut ürünlerin bileşenlerinden tamamen farklı olan yeni } \\
\text { ürünler geliştirilmesi }\end{array}$ & 86,31 & 423,29 & 0,78 & 0,97 \\
\hline $\begin{array}{l}\text { 6.Üretim süreçlerinde katma değeri olmayan faaliyetlerin } \\
\text { belirlenmesi ve ortadan kaldırılması }\end{array}$ & 86,06 & 433,61 & 0,79 & 0,97 \\
\hline $\begin{array}{l}\text { 7.Üretim süreçlerinde teknikler, Makine ve yazılım gibi değişken } \\
\text { maliyet unsurlarının azaltılması }\end{array}$ & 85,95 & 432,53 & 0,83 & 0,97 \\
\hline $\begin{array}{l}\text { 8.Üretim süreçlerinde, tekniklerde, makinelerde ve yazılımlarda } \\
\text { çıktı kalitesinin artırılması }\end{array}$ & 85,93 & 433,57 & 0,84 & 0,97 \\
\hline $\begin{array}{l}\text { 9. Teslimat ile ilgili süreçlerde katma değer yaratmayan faaliyetlerin } \\
\text { belirlenmesi ve ortadan kaldırılması }\end{array}$ & 85,99 & 434,62 & 0,80 & 0,97 \\
\hline $\begin{array}{l}\text { 10.Teslimat ile ilgili lojistik süreçlerinde değişken maliyetlerin } \\
\text { azaltılması ve / veya sevkiyat hızının arttırılması ürünler } \\
\text { geliştirilmesi }\end{array}$ & 85,99 & 430,71 & 0,83 & 0,97 \\
\hline $\begin{array}{l}\text { 11.Görünüm, ambalaj, şekil ve hacim gibi değişikliklerle temel } \\
\text { teknik ve işlevsel özelliklerini değiştirmeden mevcut ve / veya yeni } \\
\text { ürünlerin tasarımını yenilemek }\end{array}$ & 86,13 & 427,85 & 0,81 & 0,97 \\
\hline $\begin{array}{l}\text { 12.Ürünün teslimatı ile ilgili lojistik süreçlerini değiştirmeden } \\
\text { dağıtım kanallarını yenilemek }\end{array}$ & 86,01 & 430,11 & 0,86 & 0,97 \\
\hline $\begin{array}{l}\text { 13.Mevcut ve / veya yeni ürünlerin tanıtımı için kullanılan ürün } \\
\text { tanıtım tekniklerini yenilemek }\end{array}$ & 85,96 & 432,24 & 0,85 & 0,97 \\
\hline $\begin{array}{l}\text { 14.Mevcut ve / veya yeni ürünlerin fiyatlaması için kullanılan ürün } \\
\text { fiyatlandırma tekniklerini yenilemek }\end{array}$ & 85,91 & 435,32 & 0,81 & 0,97 \\
\hline 15.Genel pazarlama yönetimi faaliyetlerini yenilemek & 85,91 & 433,68 & 0,79 & 0,97 \\
\hline $\begin{array}{l}\text { 16.Firma faaliyetlerini yenilikçi bir tarzda yürütmek için kullanılan } \\
\text { usul ve süreçleri yenilemek }\end{array}$ & 85,84 & 441,70 & 0,75 & 0,97 \\
\hline 17.Tedarik zinciri yönetim sistemini yenilemek & 85,86 & 440,32 & 0,75 & 0,97 \\
\hline 18.Üretim ve kalite yönetim sistemlerini yenilemek & 85,90 & 438,02 & 0,79 & 0,97 \\
\hline 19.İnsan kaynakları yönetim sisteminin yenilenmesi & 85,94 & 432,62 & 0,83 & 0,97 \\
\hline $\begin{array}{l}\text { 20.Şirket içi yönetim bilgi sistemini ve bilgi paylaşımı } \\
\text { uygulamasını yenilemek }\end{array}$ & 85,87 & 435,16 & 0,79 & 0,97 \\
\hline $\begin{array}{l}\text { 21.Ekip çalışmasını kolaylaştırmak için organizasyon yapısını } \\
\text { yenilemek }\end{array}$ & 85,92 & 434,54 & 0,77 & 0,97 \\
\hline $\begin{array}{l}\text { 22.Pazarlama ve üretim gibi farklı işlevler arasında koordinasyonu } \\
\text { kolaylaştırmak için organizasyon yapısını yenilemek }\end{array}$ & 85,88 & 437,26 & 0,74 & 0,97 \\
\hline $\begin{array}{l}\text { 23.Proje türü organizasyonunu kolaylaştırmak için organizasyon } \\
\text { yapısını yenilemek }\end{array}$ & 85,81 & 438,56 & 0,78 & 0,97 \\
\hline $\begin{array}{l}\text { 24.Stratejik ortaklıklar ve uzun vadeli iş işbirliğini kolaylaştırmak } \\
\text { için organizasyon yapısını yenilemek }\end{array}$ & 85,79 & 436,97 & 0,77 & 0,97 \\
\hline
\end{tabular}

Cronbach's Alpha= 0,975

Tablo 1'de görüldüğü üzere inovasyon ölçümüne dair maddesel analiz sonuçları irdelendiğinde, herhangi bir ifadeyle diğer ifadeler arasındaki ilişki düzeyinin 0,30 değerinin altında gerçekleşmemesi gerekliliğinden, inovasyon ölçümünde kullanılan bir ifadenin diğer ifadelerle ilişkisi 0,30'un altında olan ifade görülmediğinden ölçekten madde çıkarımına gerek olmadığı belirlenmiştir. 24 
maddelik ölçeğin genel güvenirlik düzeyinin yüksek seviyede olduğu belirlenmiştir (Cronbach's Alpha=0,975).

Tablo 2. İnovasyon Ölçeğinin Madde-Toplam Puan Korelasyon Analiz Değerleri

\begin{tabular}{cccccc}
\hline İfadeler & $\mathrm{r}$ & $\mathrm{p}$ & Ifadeler & $\mathrm{r}$ & $\mathrm{p}$ \\
\hline 1 & 0,716 & $0,000^{* *}$ & 13 & 0,860 & $0,000^{* *}$ \\
\hline 2 & 0,743 & $0,000^{* *}$ & 14 & 0,823 & $0,000^{* *}$ \\
\hline 3 & 0,767 & $0,000^{* *}$ & 15 & 0,809 & $0,000^{* *}$ \\
\hline 4 & 0,779 & $0,000^{* *}$ & 16 & 0,767 & $0,000^{* *}$ \\
\hline 5 & 0,804 & $0,000^{* *}$ & 17 & 0,766 & $0,000^{* *}$ \\
\hline 6 & 0,811 & $0,000^{* *}$ & 18 & 0,804 & $0,000^{* *}$ \\
\hline 7 & 0,845 & $0,000^{* *}$ & 19 & 0,844 & $0,000^{* *}$ \\
\hline 8 & 0,851 & $0,000^{* *}$ & 20 & 0,810 & $0,000^{* *}$ \\
\hline 9 & 0,813 & $0,000^{* *}$ & 21 & 0,790 & $0,000^{* *}$ \\
\hline 10 & 0,842 & $0,000^{* *}$ & 22 & 0,763 & $0,000^{* *}$ \\
\hline 11 & 0,825 & $0,000^{* *}$ & 23 & 0,798 & $0,000^{* *}$ \\
\hline 12 & 0,875 & $0,000^{* *}$ & 24 & 0,792 & $0,000^{* *}$ \\
\hline$* \mathrm{p}<0.01$ & & & &
\end{tabular}

İnovasyon ölçeği madde-toplam korelasyonu değerlerine bakıldığında ( Tablo 2) ölçekte bulunan 24 ifadenin maddetoplam puan korelasyonunun $\mathrm{p}<0,01$ önem düzeyinde anlamlı bulunduğu ve ifadelerin toplam korelasyon değerlerinin, ,716 ile ,875 arasında gerçekleştiği belirlenmiştir. Bu bulgulara göre ölçekteki kalan ifadelerin birbirini desteklediğini göstermektedir.

Tablo 3: İnovasyon Ölçeğine İlişkin KMO ve Bartlett Testi Sonucu

\begin{tabular}{llr}
\hline & Kaiser-Meyer-Olkin Testi (KMO) & 0,899 \\
\hline Bartlett's Testi & Ki-kare & 4950,515 \\
\cline { 2 - 3 } & Sd & 276 \\
\cline { 2 - 3 } & p. & 0,000 \\
\hline
\end{tabular}

Tablo 3 incelendiğinde, KMO katsayısının 0,899 olarak gerçekleştiği ve Bartlett's testi neticesiyse $p<0,01$ önem düzeyinde anlamlı olarak gerçekleştiği görülmüştür. Ulaşılan bulgulara göre örneklem büyüklüğü için faktör analizi yapılabilir sınırlarda olması uygunluk düzeyini ortaya koymaktadır. $\mathrm{Bu}$ bulgular esas alınarak 24 ifadelik
Anket formunda inovasyon ölçeğine ait toplam 24 sorudan oluşan ölçeğin faktör analizinde aranan ön şart olarak kabul edilen, değişkenlerin birbirleri arasında belli oran çerçevesinde korelasyon bulunmak zorunluluğu ve KMO değerinin kabul edilebilir alt değer olan 0.60'ın üzerinde olması gerekliliğine uymaktadır. KMO örnekleme katılan katılımcı sayısının faktör analizi yapılabilmesi için yeterli sayıya sahip olup olmadığını ölçmektedir.

Tablo 4. İnovasyon Ölçümü Ölçeğine İlişkin Faktör Analizi Sonuçları

\begin{tabular}{|c|c|c|c|c|c|c|c|c|c|}
\hline \multirow[b]{2}{*}{ 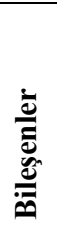 } & \multicolumn{3}{|c|}{ Başlangıç Öz değerleri } & \multicolumn{3}{|c|}{ Yüklerin Kareler Toplamı } & \multicolumn{3}{|c|}{ Döndürme Sonrası Yüklerin Kareler Toplamı } \\
\hline & $\frac{\Xi}{\frac{\Xi}{a}}$ & 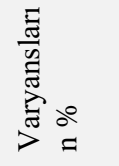 & 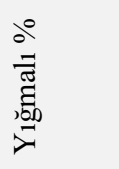 & $\frac{\Xi}{\frac{\pi}{2}}$ & 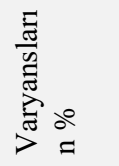 & 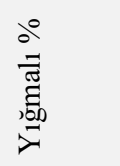 & $\frac{\Xi}{\frac{\pi}{0}}$ & 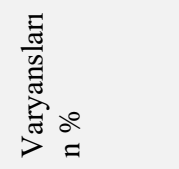 & 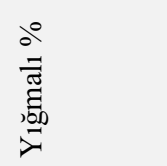 \\
\hline 1 & 15,577 & 64,903 & 64,903 & 15,577 & 64,903 & 64,903 & 5,604 & 23,351 & 23,351 \\
\hline 2 & 1,980 & 8,248 & 73,151 & 1,980 & 8,248 & 73,151 & 5,250 & 21,875 & 45,226 \\
\hline 3 & 1,468 & 6,118 & 79,270 & 1,468 & 6,118 & 79,270 & 4,709 & 19,621 & 64,847 \\
\hline 4 & 1,075 & 4,061 & 83,331 & 0,975 & 4,061 & 83,331 & 4,436 & 18,484 & 83,331 \\
\hline . & . & . & & & & & & & \\
\hline . & . & . & & & & & & & \\
\hline . & . & . & & & & & & & \\
\hline . & . & . & & & & & & & \\
\hline • & . & . & & & & & & & \\
\hline
\end{tabular}




\begin{tabular}{llll}
\hline$\cdot$ & $\cdot$ & $\cdot$ & \\
\hline $\mathbf{2 4}$ & 0,010 & 0,043 & 100,000 \\
\hline
\end{tabular}

Tablo 4'de görüldüğü gibi 24 maddelik inovasyon ölçümü ölçeğinin 4 faktörlü bir yapıda çıktığı ve 4 faktör toplam varyansın \%83,331'ini açıkladığı görülmüştür. Birinci faktör toplam varyansın \%23,351'ini, ikinci faktör toplam varyansın \%21,875'ini, üçüncü faktör toplam varyansın $\% 19,621$ 'ini ve dördüncü faktör toplam varyansın $\% 18,484$ 'ünü açıkladığı belirlenmiştir.

Tablo 5. İnovasyon Ölçümü Ölçeğine İlişkin Faktör Yapısına Göre Dağılımı

\begin{tabular}{|c|c|c|c|c|}
\hline \multirow[t]{2}{*}{ Maddeler } & \multicolumn{4}{|c|}{ Faktörler } \\
\hline & 1 & 2 & 3 & 4 \\
\hline $\begin{array}{l}\text { 5. Teslimat ile ilgili lojistik süreçlerinde değişken maliyetlerin azaltılması ve / veya } \\
\text { sevkiyat hızının arttırılması ürünler geliştirilmesi }\end{array}$ & 0,769 & & & \\
\hline $\begin{array}{l}\text { 1. Üretim süreçlerinde katma değeri olmayan faaliyetlerin belirlenmesi ve ortadan } \\
\text { kaldırılması }\end{array}$ & 0,776 & & & \\
\hline $\begin{array}{l}\text { 3. Üretim süreçlerinde, tekniklerde, makinelerde ve yazılımlarda çıktı kalitesinin } \\
\text { artırılması }\end{array}$ & 0,834 & & & \\
\hline $\begin{array}{l}\text { 2. Üretim süreçlerinde teknikler, Makine ve yazılım gibi değişken maliyet } \\
\text { unsurlarının azaltılması }\end{array}$ & 0,835 & & & \\
\hline $\begin{array}{l}\text { 4. Teslimat ile ilgili süreçlerde katma değer yaratmayan faaliyetlerin belirlenmesi ve } \\
\text { ortadan kaldırılması }\end{array}$ & 0,836 & & & \\
\hline $\begin{array}{l}\text { 3. Mevcut ve / veya yeni ürünlerin tanıtımı için kullanılan ürün tanıtım tekniklerini } \\
\text { yenilemek }\end{array}$ & & 0,499 & & \\
\hline $\begin{array}{l}\text { 4. Mevcut ve / veya yeni ürünlerin fiyatlaması için kullanılan ürün fiyatlandırma } \\
\text { tekniklerini yenilemek }\end{array}$ & & 0,502 & & \\
\hline $\begin{array}{l}\text { 2. Ürünün teslimatı ile ilgili lojistik süreçlerini değiştirmeden dağıtım kanallarını } \\
\text { yenilemek }\end{array}$ & & 0,556 & & \\
\hline $\begin{array}{l}\text { 1. Görünüm, ambalaj, şekil ve hacim gibi değişikliklerle temel teknik ve işlevsel } \\
\text { özelliklerini değiştirmeden mevcut ve / veya yeni ürünlerin tasarımını yenilemek }\end{array}$ & & 0,587 & & \\
\hline 5. Genel pazarlama yönetimi faaliyetlerini yenilemek & & 0,617 & & \\
\hline 5. Mevcut ürünlerin bileşenlerinden tamamen farklı olan yeni ürünler geliştirilmesi & & & 0,525 & \\
\hline $\begin{array}{l}\text { 4. Mevcut olanlardan farklı teknik özelliklere ve işlevlere sahip yeni ürünler } \\
\text { geliştirilmesi }\end{array}$ & & & 0,733 & \\
\hline $\begin{array}{l}\text { 3. Müşteriler için geliştirilmiş kullanım kolaylığına ve mevcut müşteri } \\
\text { memnuniyetine yol açan mevcut ürünlerin yeniden geliştirilmesi }\end{array}$ & & & 0,847 & \\
\hline 1. Mevcut ürünlerin imalat kalitesindeki bileşenlerinin ve malzemelerinin arttırılması & & & 0,862 & \\
\hline 2. Mevcut ürünlerin bileşenleri ve malzemelerindeki üretim maliyetinin düşürülmesi & & & 0,895 & \\
\hline 4. İnsan kaynakları yönetim sisteminin yenilenmesi & & & & 0,671 \\
\hline 5. Şirket içi yönetim bilgi sistemini ve bilgi paylaşımı uygulamasını yenilemek & & & & 0,692 \\
\hline 6. Ekip çalışmasını kolaylaştırmak için organizasyon yapısını yenilemek & & & & 0,742 \\
\hline $\begin{array}{l}\text { 1. Firma faaliyetlerini yenilikçi bir tarzda yürütmek için kullanılan usul ve süreçleri } \\
\text { yenilemek }\end{array}$ & & & & 0,760 \\
\hline 8. Proje türü organizasyonunu kolaylaştırmak için organizasyon yapısını yenilemek & & & & 0,761 \\
\hline 3. Üretim ve kalite yönetim sistemlerini yenilemek & & & & 0,795 \\
\hline 2. Tedarik zinciri yönetim sistemini yenilemek & & & & 0,822 \\
\hline $\begin{array}{l}\text { 7. Pazarlama ve üretim gibi farklı işlevler arasında koordinasyonu kolaylaştırmak için } \\
\text { organizasyon yapısını yenilemek }\end{array}$ & & & & 0,833 \\
\hline $\begin{array}{l}\text { 9. Stratejik ortaklıklar ve uzun vadeli iş işbirliğini kolaylaştırmak için organizasyon } \\
\text { yapısını yenilemek }\end{array}$ & & & & 0,719 \\
\hline
\end{tabular}

Faktör yüklerine göre ifadelerin toplandıkları faktörlerdeki yüklerin birbirine uzaklığının en az \%10 olması istenmektedir. \%10'un altında olan ifadeler olmadığından faktör analizi sonucuna göre madde çıkarımı yapılmasına gerek görülmemiştir. Faktörlerin birbirleri arasında içsel tutarlılığının hesaplanmasında, Cronbach Alpha değeri kullanılmıştır. Cronbach alpha değerinin 0.70'in üzerinde olması güvenirliğinin yeterli düzeyde olduğu anlamına gelmektedir.
Faktörler incelendiğinde;

Faktör 1:

1. faktör altında 5 ifade toplanmış ve bu ifadeler ile yük değerleri ve diğer istatistiksel değerler Tablo 6' da gösterilmiştir. Bu faktöre ait toplanan ifadelere bakıldığında faktör "Süreç İnovasyonu Ölçümü" olarak adlandırılmıştır. 
Tablo 6.Süreç İnovasyonu Ölçümü

\begin{tabular}{lcc}
\hline FAKTÖR 1: Süreç İnovasyonu Ölçümü & Faktör Yükü & Faktör Güvenirliği \\
\hline $\begin{array}{l}\text { 5.Teslimat ile ilgili lojistik süreçlerinde değişken maliyetlerin azaltılması ve / veya sevkiyat } \\
\text { hızının arttırılması ürünler geliştirilmesi }\end{array}$ & 0,769 \\
\hline $\begin{array}{l}\text { 1.Üretim süreçlerinde katma değeri olmayan faaliyetlerin belirlenmesi ve ortadan } \\
\text { kaldırılması }\end{array}$ & 0,776 \\
\hline $\begin{array}{l}\text { 3.Üretim süreçlerinde, tekniklerde, makinelerde ve yazılımlarda çıktı kalitesinin artırılması } \\
\text { 2.Üretim süreçlerinde teknikler, Makine ve yazılım gibi değişken maliyet unsurlarının } \\
\text { azaltılması }\end{array}$ & 0,834 \\
\hline $\begin{array}{l}\text { 4.Teslimat ile ilgili süreçlerde katma değer yaratmayan faaliyetlerin belirlenmesi ve ortadan } \\
\text { kaldırılması }\end{array}$ & 0,835 \\
\hline
\end{tabular}

\section{Faktör 2:}

2. faktör altında 5 ifade toplanmış ve bu ifadeler ile yük değerleri ve diğer istatistiksel değerler Tablo 7'de Tablo 7.Pazarlama İnovasyonu Ölçümü gösterilmiştir. Bu faktöre ait toplanan ifadelere bakıldığında faktör "Pazarlama İnovasyonu Ölçümü" olarak adlandırılmıştır.

\begin{tabular}{lcc}
\hline FAKTÖR 2: Pazarlama İnovasyonu Ölçümü & Faktör Yükü & Faktör Güvenirliği \\
\hline 3.Mevcut ve / veya yeni ürünlerin tanıtımı için kullanılan ürün tanıtım tekniklerini yenilemek & 0,499 \\
\hline $\begin{array}{l}\text { 4.Mevcut ve / veya yeni ürünlerin fiyatlaması için kullanılan ürün fiyatlandırma tekniklerini } \\
\text { yenilemek }\end{array}$ & 0,502 \\
\hline $\begin{array}{l}\text { 2.Ürünün teslimatı ile ilgili lojistik süreçlerini değiştirmeden dağıtım kanallarını yenilemek } \\
\text { l.Görünüm, ambalaj, şekil ve hacim gibi değişikliklerle temel teknik ve işlevsel özelliklerini } \\
\text { değiştirmeden mevcut ve / veya yeni ürünlerin tasarımını yenilemek }\end{array}$ & 0,556 \\
\hline 5.Genel pazarlama yönetimi faaliyetlerini yenilemek & 0,587 \\
\hline
\end{tabular}

Pazarlama inovasyonu ölçümü faktörüne ait faktör yükleri 0,499 ile 0,617 arasında gerçekleştiği tespit edilmiştir.

\section{Faktör 3:}

3. faktör altında 5 ifade toplanmış ve bu ifadeler ile yük değerleri ve diğer istatistiksel değerler Tablo 8 'de gösterilmiştir. Bu faktöre ait toplanan ifadeler ele alındığında faktör "Ürün İnovasyonu Ölçümü” olarak adlandırılmıştır.

Tablo 8. Ürün İnovasyonu Ölçümü

\begin{tabular}{lcc}
\hline FAKTÖR 3: Ürün İnovasyonu Ölçümü & Faktör Yükü & Faktör Güvenirliği \\
\hline 5.Mevcut ürünlerin bileşenlerinden tamamen farklı olan yeni ürünler geliştirilmesi & 0,525 \\
\hline 4.Mevcut olanlardan farklı teknik özelliklere ve işlevlere sahip yeni ürünler geliştirilmesi & 0,733 \\
\hline $\begin{array}{l}\text { 3.Müşteriler için geliştirilmiş kullanım kolaylığına ve mevcut müşteri memnuniyetine yol } \\
\text { açan mevcut ürünlerin yeniden geliştirilmesi }\end{array}$ & 0,847 \\
\hline 1.Mevcut ürünlerin imalat kalitesindeki bileşenlerinin ve malzemelerinin arttırılması & 0,862 \\
\hline 2.Mevcut ürünlerin bileşenleri ve malzemelerindeki üretim maliyetinin düşürülmesi & 0,895 \\
\hline
\end{tabular}

Ürün inovasyonu ölçümü faktörüne ait faktör yükleri 0,525 ile 0,895 arasında olduğu belirlenmiştir.

\section{Faktör 4:}

4. faktör altında 9 ifade toplanmış ve bu ifadeler ile yük değerleri ve diğer istatistiksel değerler Tablo 9'da gösterilmiştir. Bu faktöre ait toplanan ifadelere bakıldığında faktörün "Organizasyonel İnovasyonu Ölçümü” olarak adlandırılması uygun görülmüştür. 
Tablo 9. Organizasyonel İnovasyonu Ölçümü

\begin{tabular}{|c|c|c|}
\hline FAKTÖR 4: Organizasyonel İnovasyonu Ölçümü & Faktör Yükü & Faktör Güvenirliği \\
\hline $\begin{array}{l}\text { 7.Pazarlama ve üretim gibi farklı işlevler arasında koordinasyonu kolaylaştırmak için } \\
\text { organizasyon yapısını yenilemek }\end{array}$ & 0,833 & \multirow{9}{*}{0,961} \\
\hline 2.Tedarik zinciri yönetim sistemini yenilemek & 0,822 & \\
\hline 3.Üretim ve kalite yönetim sistemlerini yenilemek & 0,795 & \\
\hline 8.Proje türü organizasyonunu kolaylaştırmak için organizasyon yapısını yenilemek & 0,761 & \\
\hline $\begin{array}{l}\text { 1.Firma faaliyetlerini yenilikçi bir tarzda yürütmek için kullanılan usul ve süreçleri } \\
\text { yenilemek }\end{array}$ & 0,760 & \\
\hline 6.Ekip çalışmasını kolaylaştırmak için organizasyon yapısını yenilemek & 0,742 & \\
\hline $\begin{array}{l}\text { 9. Stratejik ortaklıklar ve uzun vadeli iş işbirliğini kolaylaştırmak için organizasyon yapısını } \\
\text { yenilemek }\end{array}$ & 0,719 & \\
\hline 5.Şirket içi yönetim bilgi sistemini ve bilgi paylaşımı uygulamasını yenilemek & 0,692 & \\
\hline 4.İnsan kaynakları yönetim sisteminin yenilenmesi & 0,671 & \\
\hline
\end{tabular}

Organizasyonel inovasyonu ölçümü faktörüne ait faktör yükleri 0,671 ile 0,833 arasında olduğu belirlenmiştir.

\subsubsection{Doğrulayıcı Faktör Analizi Sonuçları}

İnovasyon ölçümü ölçeğinin alt boyutlarının yer aldığı DFA sonuçları Şekil 1 ve Tablo 10'da verilmiştir.

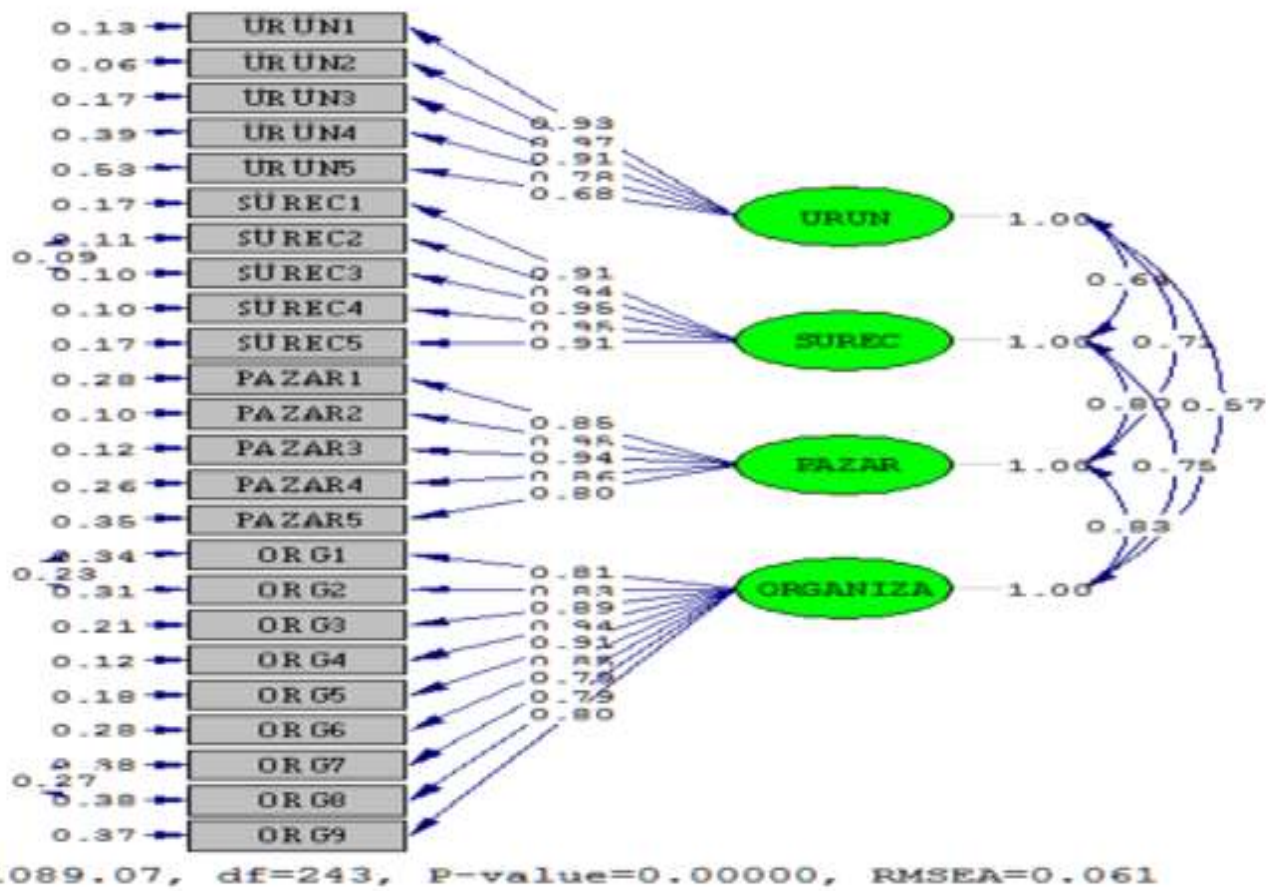

Şekil 1. İnovasyon Ölçümü Ölçeğine İlişkin DFA Analizi Sonuçları

Tablo 10. İnovasyon Ölçeğine Ait Ölçüm Modelleri Sonucu

\begin{tabular}{lllll}
\hline Faktör/Madde & Standartlaştırılmış Yükler & t-değeri & $\mathrm{R}^{2}$ \\
\hline Ürün İnovasyonu Ölçümü & & 14,28 & 0,87 \\
\hline ÜRÜN1 & 0,93 & 15,38 & 0,94 \\
\hline ÜRÜN2 & 0,97 & 13,68 & 0,83 \\
\hline ÜRÜN3 & 0,91 & 10,78 & 0,61 \\
\hline ÜRÜN4 & 0,78 & 8,96 & 0,47 \\
\hline ÜRÜN5 & 0,68 & 13,69 & 14,51 \\
\hline Süreç İnovasyonu Ölçümü & & 0,83 \\
\hline SÜREC1 & 0,91 & 0,88 \\
\hline SÜREC2 & 0,94 & & \\
\hline
\end{tabular}




\begin{tabular}{|c|c|c|c|}
\hline SÜREC3 & 0,95 & 14,76 & 0,90 \\
\hline SÜREC4 & 0,95 & 14,74 & 0,90 \\
\hline SÜREC5 & 0,91 & 13,71 & 0,83 \\
\hline \multicolumn{4}{|c|}{ Pazarlama İnovasyonu Ölçümü } \\
\hline PAZAR1 & 0,85 & 12,20 & 0,72 \\
\hline PAZAR2 & 0,95 & 14,65 & 0,90 \\
\hline PAZAR3 & 0,94 & 14,35 & 0,88 \\
\hline PAZAR4 & 0,86 & 12,47 & 0,74 \\
\hline PAZAR5 & 0,80 & 11,17 & 0,64 \\
\hline \multicolumn{4}{|c|}{ Organizasyonel İnovasyonu Ölçümü } \\
\hline ORG1 & 0,81 & 11,33 & 0,66 \\
\hline ORG2 & 0,83 & 11,73 & 0,69 \\
\hline ORG3 & 0,89 & 13,09 & 0,79 \\
\hline ORG4 & 0,94 & 14,44 & 0,88 \\
\hline ORG5 & 0,91 & 13,61 & 0,83 \\
\hline ORG6 & 0,85 & 12,22 & 0,72 \\
\hline ORG7 & 0,79 & 10,89 & 0,62 \\
\hline ORG8 & 0,79 & 10,82 & 0,62 \\
\hline ORG9 & 0,80 & 11,02 & 0,64 \\
\hline
\end{tabular}

İnovasyon ölçeğine ait DFA analizi yapılırken ölçeğin alt boyutları URUN= Ürün İnovasyonu Ölçümü, SUREC $=$ Süreç İnovasyonu Ölçümü, PAZAR = Pazarlama İnovasyonu Ölçümü, ORGANIZA = Organizasyonel İnovasyonu Ölçümü şeklinde isimlendirilmiştir.

İnovasyon alt boyutlarından ürün inovasyon ölçümünde 0,97'lik katsayı ile URUN2 "Mevcut ürünlerin bileşenleri ve malzemelerindeki üretim maliyetinin düşürülmesi" maddesi en etkili değişken olarak belirlenirken, süreç inovasyon ölçümü boyutu üzerinde 0,95'lik katsayı ile SUREC3 "Üretim süreçlerinde, tekniklerde, makinelerde ve yazılımlarda çıktı kalitesinin artırılması" ve SUREC 4" Teslimat ile ilgili süreçlerde katma değer yaratmayan faaliyetlerin belirlenmesi ve ortadan kaldırılması" maddeleri en etkili değişken olarak belirlenirken, Pazarlama inovasyon ölçümü boyutu üzerinde 0,95'lik katsayı ile PAZAR2= "Ürünün teslimatı ile ilgili lojistik süreçlerini değiştirmeden dağıtım kanallarını yenilemek" değişkeni en etkili değişken olarak belirlenirken, Organizasyonel İnovasyonu Ölçümü boyutu üzerinde 0,94'lük katsayı ORG4 “İnsan kaynakları yönetim sisteminin yenilenmesi” değişkeni en etkili değişken olduğu belirlenmiştir.

Tablo 11. İnovasyon Ölçümü Ölçeği Alt Boyutlarına Ait Ölçüm Sonucu İlişki Değerleri

\begin{tabular}{|c|c|c|c|c|}
\hline & $\begin{array}{c}\text { Ürün } \\
\text { İnovasyonu } \\
\text { Ölçümü }\end{array}$ & $\begin{array}{c}\text { Süreç } \\
\text { İnovasyonu } \\
\text { Ölçümü }\end{array}$ & $\begin{array}{c}\text { Pazarlama } \\
\text { İnovasyonu } \\
\text { Ölçümü }\end{array}$ & $\begin{array}{c}\text { Organizasyonel } \\
\text { İnovasyonu Ölçümü }\end{array}$ \\
\hline Ürün İnovasyonu Ölçümü & 1 & & & \\
\hline Süreç İnovasyonu Ölçümü & $0,64 *$ & 1 & & \\
\hline Pazarlama İnovasyonu Ölçümü & $0,71 *$ & $0,80 *$ & 1 & \\
\hline Organizasyonel İnovasyonu Ölçümü & $0,57 *$ & $0,75^{*}$ & $0,83 *$ & 1 \\
\hline
\end{tabular}

Tablo 11 incelendiğinde alt boyutlar arasında en yüksek ilişkinin organizasyonel inovasyon ölçümü ile pazarlama inovasyonu ölçümü arasında 0,83'lük ilişki olduğu ve bu ilişkinin anlamlı olduğu belirlenmiştir $(\mathrm{p}<0.05)$. Organizasyon inovasyon ölçümünde artış olduğunda, pazarlama inovasyonu ölçümünde pozitif yönde kuvvetli bir artış olacağ belirlenmiştir. $(\mathrm{p}<0.05, \mathrm{r}=0,830)$
Çalışmanın uygulama kısmında kurulan DFA'lara ait uyum kriterlerinin yer aldığı Tablo 12 incelendiğinde İnovasyon ölçeğine ilişkin DFA analizi için uyum kriterlerin geneli için kabul edilebilir uyum sınırlar arasında yer aldığını söylemek mümkündür. Bu kriterler dişında $\chi^{2}(243)=1089,07 ; \chi 2 / s d$ $=4,48<5$ değeri de model uygunluğunun belirlenmesinde kullanılan diğer bir istatistik olup, modelin istatistiki açıdan uygun olduğunun diğer bir göstergesidir. 
Tablo 12. Kurulan İnovasyon Ölçeğinin DFA Modeli İçin Uyum Kriterlerine Ait Değerler

\begin{tabular}{cccc}
\hline $\begin{array}{c}\text { Uyum } \\
\text { Kriterleri }\end{array}$ & Mükemmel Uyum & Kabul Edilebilir Uyum & $\begin{array}{c}\text { Geliştirilen Ölçeğe Ait } \\
\text { Değerler }\end{array}$ \\
\hline$\chi 2 / s d$ & $\leq 3$ & $\leq 5$ & 4,480 \\
\hline RMSEA & $0<\mathrm{RMSEA}<0.05$ & $0.05 \leq \mathrm{RMSEA} \leq 0.10$ & 0,061 \\
\hline SRMR & $0 \leq \mathrm{SRMR}<0.05$ & $0.05 \leq \mathrm{SRMR} \leq 0.10$ & 0,090 \\
\hline NFI & $0.95 \leq \mathrm{NFI} \leq 1$ & $0.90 \leq \mathrm{NFI} \leq 0.95$ & 0,920 \\
\hline NNFI & $0.95 \leq \mathrm{NNFI} \leq 1$ & $0.90 \leq \mathrm{NNFI} \leq 0.95$ & 0,930 \\
\hline CFI & $0.95 \leq \mathrm{CFI} \leq 1$ & $0.90 \leq \mathrm{CFI} \leq 0.95$ & 0,930 \\
\hline GFI & $0.95 \leq \mathrm{GFI} \leq 1$ & $0.90 \leq \mathrm{GFI} \leq 0.95$ & 0,910 \\
\hline IFI & $0.95 \leq \mathrm{CFI} \leq 1$ & $0.90 \leq \mathrm{IFI} \leq 0.95$ & 0,910 \\
\hline RFI & $0.95 \leq \mathrm{RFI} \leq 1$ & $0.90 \leq \mathrm{RFI} \leq 0.95$ & 0,900 \\
\hline AGFI & $0.90 \leq \mathrm{AGFI} \leq 1$ & $0.85 \leq \mathrm{AGFI} \leq 0.90$ & \\
\hline
\end{tabular}

Kaynak: (Schermelleh-Engel vd., 2003)

Tablo 12 incelendiğinde, inovasyon ölçeğine ait $\chi 2 / s d$, (RMSEA, SRMR, NFI, NNFI, GFI, AGFI, IFI, RFI $)^{l}$ değerlerin kabul edilebilir uyum kriterleri içerisinde olduğu belirlenmiştir.

Tablo 13. Performans Ölçümü Ölçeğine İlişkin Faktör ve Güvenirlik Analizleri Sonuçları

\begin{tabular}{|c|c|c|c|c|}
\hline Maddeler & $\begin{array}{c}\text { Öğe } \\
\text { Silindiğinde } \\
\text { Ölçek } \\
\text { Ortalması } \\
\end{array}$ & $\begin{array}{c}\text { Öğe } \\
\text { Silindiğinde } \\
\text { Varyans } \\
\text { Ortalaması } \\
\end{array}$ & $\begin{array}{l}\text { Düzeltilmiş } \\
\text { Madde- } \\
\text { Toplam } \\
\text { Korelasyon } \\
\end{array}$ & $\begin{array}{c}\text { Öğe } \\
\text { Silindiğinde } \\
\text { Cronbach's } \\
\text { Alpha } \\
\end{array}$ \\
\hline $\begin{array}{l}\text { 1.Rakiplerden önce pazara yeni ürün ve hizmetler sunma } \\
\text { becerisi }\end{array}$ & 63,44 & 172,37 & 0,88 & 0,97 \\
\hline 2.Mevcut ürün portföyünde yeni ürün yüzdesi & 63,47 & 170,85 & 0,91 & 0,97 \\
\hline 3.Yeni ürün ve hizmet projelerinin sayısı & 63,49 & 170,66 & 0,91 & 0,97 \\
\hline 4.İ̧s süreçleri ve yöntemleri için sunulan yenilikler & 63,46 & 170,89 & 0,91 & 0,97 \\
\hline 5.Yeni ürünlerin ve hizmetlerin kalitesi tanıtıldı & 63,49 & 171,07 & 0,87 & 0,97 \\
\hline 6.Fikri mülkiyet koruması altındaki inovasyon sayısı & 63,97 & 169,85 & 0,72 & 0,98 \\
\hline $\begin{array}{l}\text { 7.İdari sistemi ve firma aklını firmanın çevre koşullarına } \\
\text { uygun olarak yenilemek }\end{array}$ & 63,41 & 174,42 & 0,76 & 0,97 \\
\hline 8.Uygunluk kalitesi & 63,30 & 180,03 & 0,83 & 0,97 \\
\hline 9.Üretim maliyeti & 63,30 & 180,61 & 0,82 & 0,97 \\
\hline 10.Üretim (hacim) esnekliği & 63,24 & 179,95 & 0,81 & 0,97 \\
\hline 11.Üretim ve teslim hızı & 63,17 & 178,59 & 0,86 & 0,97 \\
\hline 12.Müşteri memnuniyeti & 63,01 & 181,52 & 0,74 & 0,97 \\
\hline 13.Toplam satı̧ & 63,20 & 178,40 & 0,81 & 0,97 \\
\hline 14.Pazar Pay1 & 63,26 & 179,28 & 0,76 & 0,97 \\
\hline 15.Satış getirisi (kâr / toplam satış) & 63,24 & 179,96 & 0,80 & 0,97 \\
\hline 16.Aktif kârlılığı (kar / toplam aktifler) & 63,22 & 179,71 & 0,84 & 0,97 \\
\hline 17.Firmanın genel karlılığ1 & 63,22 & 179,58 & 0,82 & 0,97 \\
\hline 18.Yatırımlar hariç nakit akışı & 63,23 & 179,98 & 0,81 & 0,97 \\
\hline \multicolumn{5}{|c|}{ Cronbach's Alpha $=0,974$} \\
\hline
\end{tabular}

1 (RMSEA: Root Mean Square Error of Approximation, SRMR: Standardized Root Mean Square Residual, GFI: Goodness of Fit Index, AGFI: AdjustedGoodness of Fit Index) 
Tablo 13'de bulunan performans ölçümü ölçeğine ilişkin madde analizi sonuçları incelendiğinde, bir maddenin diğer maddelerle olan ilişkisinin 0,30'un altında olmaması gerektiğinden, performans ölçümü ölçeğinde bir maddenin diğer maddelerle ilişkisi 0,30'un altında olan madde

Tablo 14. Performans Ölçeğinin Madde-Toplam Puan Korelasyonu Değerleri olmadığından ölçekten madde çıkarımına gerek olmadığ belirlenmiştir. 18 maddelik ölçeğin genel güvenirlik düzeyinin yüksek seviyede olduğu belirlenmiştir (Cronbach's Alpha= 0,974

\begin{tabular}{cccccc}
\hline Maddeler & \multicolumn{1}{c}{$\mathbf{p}$} & Maddeler & $\mathbf{r}$ & $\mathbf{p}$ \\
\hline $\mathbf{1}$ & 0,893 & $0,000^{* *}$ & 10 & 0,832 & $0,000^{* *}$ \\
\hline $\mathbf{2}$ & 0,925 & $0,000^{* *}$ & 11 & 0,871 & $0,000^{* *}$ \\
\hline $\mathbf{3}$ & 0,919 & $0,000^{* *}$ & 12 & 0,765 & $0,000^{* *}$ \\
\hline $\mathbf{4}$ & 0,924 & $0,000^{* *}$ & 13 & 0,831 & $0,000^{* *}$ \\
\hline $\mathbf{5}$ & 0,886 & $0,000^{* *}$ & 14 & 0,782 & $0,000^{* * *}$ \\
\hline $\mathbf{6}$ & 0,761 & $0,000^{* *}$ & 15 & 0,822 & $0,000^{* *}$ \\
\hline $\mathbf{7}$ & 0,793 & $0,000^{* *}$ & 16 & 0,853 & $0,000^{* *}$ \\
\hline $\mathbf{8}$ & 0,847 & $0,000^{* *}$ & 17 & 0,84 & $0,000^{* *}$ \\
\hline $\mathbf{9}$ & 0,841 & $0,000^{* *}$ & 18 & 0,828 \\
\hline
\end{tabular}

Performans ölçeği madde-toplam korelasyonu değerleri incelendiğinde ( Tablo 14) ölçekte bulunan 18 maddenin madde-toplam puan korelasyonunun $p<0,01$ önem düzeyinde anlamlı bulunduğu ve maddelerin toplam Tablo 15. İnovasyon Ölçeğine İlişkin KMO ve Bartlett Testi Sonucu korelasyon değerlerinin ,761 ile ,925 arasında değiştiği belirlenmiştir. Bu bulgular ölçekte kalan maddelerin sorunlu olmadığını göstermektedir.

Kaiser-Meyer-Olkin Testi (KMO)

\begin{tabular}{lc} 
Ki-kare & 3718,61 \\
\hline Sd & 153 \\
\hline p. & 0,000
\end{tabular}

Tablo 15 incelendiğinde, KMO katsayısının 0,933 olduğu ve Bartlett's testi sonucunun ise $\mathrm{p}<0,01$ önem düzeyinde anlamlı olduğu belirlenmiştir. $\mathrm{Bu}$ bulgular örneklem büyüklüğünün faktör analizi yapılması için uygun olduğunu göstermektedir.

Tablo 16. Performans Ölçümü Ölçeğine İlişkin Faktör Analizi Sonuçları
$\mathrm{Bu}$ bulgulara dayanarak 18 maddelik performans ölçeğinin açıklayıcı faktör analizi olarak temel bileşenler yöntemi ve varimax döndürmesi uygulanmıştır. 18 maddelik ölçekte faktör analizi sonucu toplam varyansın \%78,966'sını açıklayan ve öz değerleri 1 'in üzerinde olan 2 faktörlü bir yapı ortaya çıktığ 1 belirlenmiştir. (Tablo 16)

\section{Başlangıç Öz değerleri}

\begin{tabular}{|c|c|c|c|c|c|c|c|c|c|}
\hline \multirow[b]{2}{*}{ 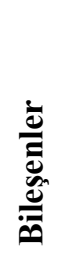 } & \multirow[b]{2}{*}{$\frac{\tilde{\Xi}}{\frac{\pi}{0}}$} & \multirow[b]{2}{*}{ 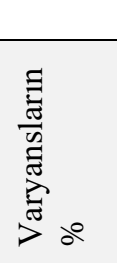 } & \multirow[b]{2}{*}{ 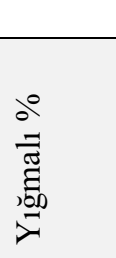 } & \multirow[b]{2}{*}{$\frac{\Xi}{\frac{\pi}{a}}$} & \multirow[b]{2}{*}{ 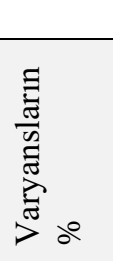 } & \multicolumn{4}{|c|}{ Kareler Toplamı } \\
\hline & & & & & & 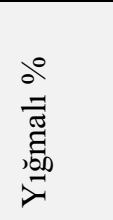 & $\frac{\Xi}{\stackrel{\Xi}{0}}$ & $\begin{array}{l}\Xi \\
\stackrel{\Xi}{\Xi} \\
\stackrel{\Xi}{\Xi} \\
\stackrel{\Xi}{J}\end{array}$ & Yığmalı \% \\
\hline 1 & 12,94 & 71,887 & 71,887 & 12,94 & 71,887 & 71,887 & 7,735 & 42,972 & 42,972 \\
\hline 2 & 1,274 & 7,078 & 78,966 & 1,274 & 7,078 & 78,966 & 6,479 & 35,994 & 78,966 \\
\hline . & . & . & & & & & & & \\
\hline . & . & . & & & & & & & \\
\hline . & . & . & & & & & & & \\
\hline - & . & . & & & & & & & \\
\hline • & . & . & & & & & & & \\
\hline
\end{tabular}




\begin{tabular}{llll}
$\cdot$ &. &. & \\
\hline$\cdot$ &. &. & \\
\hline$\cdot$ & . & . & \\
\hline $\mathbf{1 8}$ & 0,014 & 0,077 & 100,000 \\
\hline
\end{tabular}

Tablo 16'da görüldüğü gibi 18 maddelik performans ölçümü ölçeğinin 2 faktörlü bir yapıda çıktığı ve 2 faktör toplam varyansın \% 78,966'sını açıkladığı görülmektedir. Birinci

Tablo 17. Performans Ölçümü Ölçeğine İlişkin Faktör Yapısına Göre Dağılımı faktör toplam varyansın \%42,972'sini, ikinci faktörün toplam varyansın \%35,994'ünü açıkladığı belirlenmiştir.

\begin{tabular}{lc}
\hline \multicolumn{1}{c}{ Maddeler } & Faktörler \\
\cline { 2 - 2 } 12.Müşteri memnuniyeti & 0,710 \\
\hline 18.Yatırımlar hariç nakit akışı & 0,738 \\
\hline 8.Uygunluk kalitesi & 0,744 \\
\hline 11.Üretim ve teslim hızı & 0,754 \\
\hline 9.Üretim maliyeti & 0,767 \\
\hline 14.Pazar Payı & 0,776 \\
\hline 13.Toplam satış & 0,777 \\
\hline 17.Firmanın genel karlılığı & 0,780 \\
\hline 10.Üretim (hacim) esnekliği & 0,781 \\
\hline 15.Satış getirisi (kâr / toplam satış) & 0,800 \\
\hline 16.Aktif kârlı̆ı̆̆ (kar / toplam aktifler) & 0,818 \\
\hline 7.İdari sistemi ve firma aklını firmanın çevre koşullarına uygun olarak yenilemek \\
\hline 6.Fikri mülkiyet koruması altındaki inovasyon sayısı \\
\hline 1.Rakiplerden önce pazara yeni ürün ve hizmetler sunma becerisi \\
\hline 4.İş süreçleri ve yöntemleri için sunulan yenilikler & 0,715 \\
\hline 2.Mevcut ürün portföyünde yeni ürün yüzdesi & 0,728 \\
\hline 3.Yeni ürün ve hizmet projelerinin sayısı & 0,809 \\
\hline 5.Yeni ürünlerin ve hizmetlerin kalitesi tanıtıldı & 0,856 \\
\hline
\end{tabular}

Faktör yüklerine göre maddelerin toplandıkları faktörlerdeki yüklerin birbirine uzaklığının en az \%10 olması eğer \%10'un altında olan maddeler olmadığından faktör analizi sonucuna göre madde çıkarımı yapılmasına gerek duyulmamıştır. Faktörlerin içsel tutarlılıklarının hesaplanmasında, Cronbach Alpha değeri kullanılmıştır. Cronbach alpha değerinin 0.70'in üzerinde olması güvenirliğinin yeterli düzeyde olduğu anlamına gelmektedir.

Tablo 18.Pazar Ürünlerinin Finansal Performans1
Faktörler incelendiğinde;

\section{Faktör 1:}

1. faktör altında 11 ifade toplanmış ve bu ifadeler ile yük değerleri ve diğer istatistiksel değerler Tablo 18'de gösterilmiştir. $\mathrm{Bu}$ faktöre ait toplanan maddeler incelendiğinde faktörün "Pazar Ürünlerinin Finansal Performansı" olarak adlandırılması uygun görülmüştür.

\begin{tabular}{lc}
\hline FAKTÖR 1: Pazar Ürünlerinin Finansal Performansı & Faktör Yükü \\
\hline 12.Müşteri memnuniyeti & 0,710 \\
\hline 18.Yatırımlar hariç nakit akışı̈1 & 0,738 \\
\hline 8.Uygunluk kalitesi & 0,744 \\
\hline 11.Üretim ve teslim hızı & 0,754 \\
\hline 9.Üretim maliyeti & 0,767 \\
\hline 14.Pazar Payı & 0,776 \\
\hline 13.Toplam satış & 0,777 \\
\hline 17.Firmanın genel karlılı̆̆1 & 0,780 \\
\hline 10.Üretim (hacim) esnekliği & 0,781 \\
\hline 15.Satış getirisi (kâr / toplam satış) & 0,800 \\
\hline 16.Aktif kârlılığ1 (kar / toplam aktifler) & 0,818 \\
\hline
\end{tabular}


Pazar ürünlerinin finansal performansı faktörüne ait faktör yükleri 0,710 ile 0,818 arasında olduğu belirlenmiştir.

\section{Faktör 2:}

Tablo 19. İnovatif Performans Ölçümü
2. faktör altında 7 ifade toplanmış ve bu ifadeler ile yük değerleri ve diğer istatistiksel değerler Tablo 19'da gösterilmiştir. $\mathrm{Bu}$ faktöre ait toplanan maddeler incelendiğinde faktör "İnovatif Performans Ölçümü" olarak adlandırılmıştır.

\begin{tabular}{|l|c|}
\hline FAKTÖR 2: İnovatif Performans Ölçümü & Faktör Yükü \\
\hline 7.İdari sistemi ve firma aklını firmanın çevre koşullarına uygun olarak yenilemek & $\begin{array}{c}\text { Faktör } \\
\text { Güvenirliği }\end{array}$ \\
\hline 6.Fikri mülkiyet koruması altındaki inovasyon sayısı & 0,715 \\
\hline 1.Rakiplerden önce pazara yeni ürün ve hizmetler sunma becerisi & 0,728 \\
\hline 4.İş süreçleri ve yöntemleri için sunulan yenilikler & 0,809 \\
\hline 2.Mevcut ürün portföyünde yeni ürün yüzdesi & 0,856 \\
\hline 3.Yeni ürün ve hizmet projelerinin sayısı & 0,862 \\
\hline 5.Yeni ürünlerin ve hizmetlerin kalitesi tanıtıldı & 0,864 \\
\hline
\end{tabular}

İnovatif Performans ölçümü faktörüne ait faktör yükleri 0,715 ile 0,868 arasında olduğu belirlenmiştir.

\subsection{2.İnovatif Performans Ölçeğine Dfa Sonuçları}

İnovatif Performans Ölçeğinin Alt Boyutlarının Yer Aldığı DFA Analizi Sonuçları Şekil 4 ve Tablo 20'de verilmiştir.

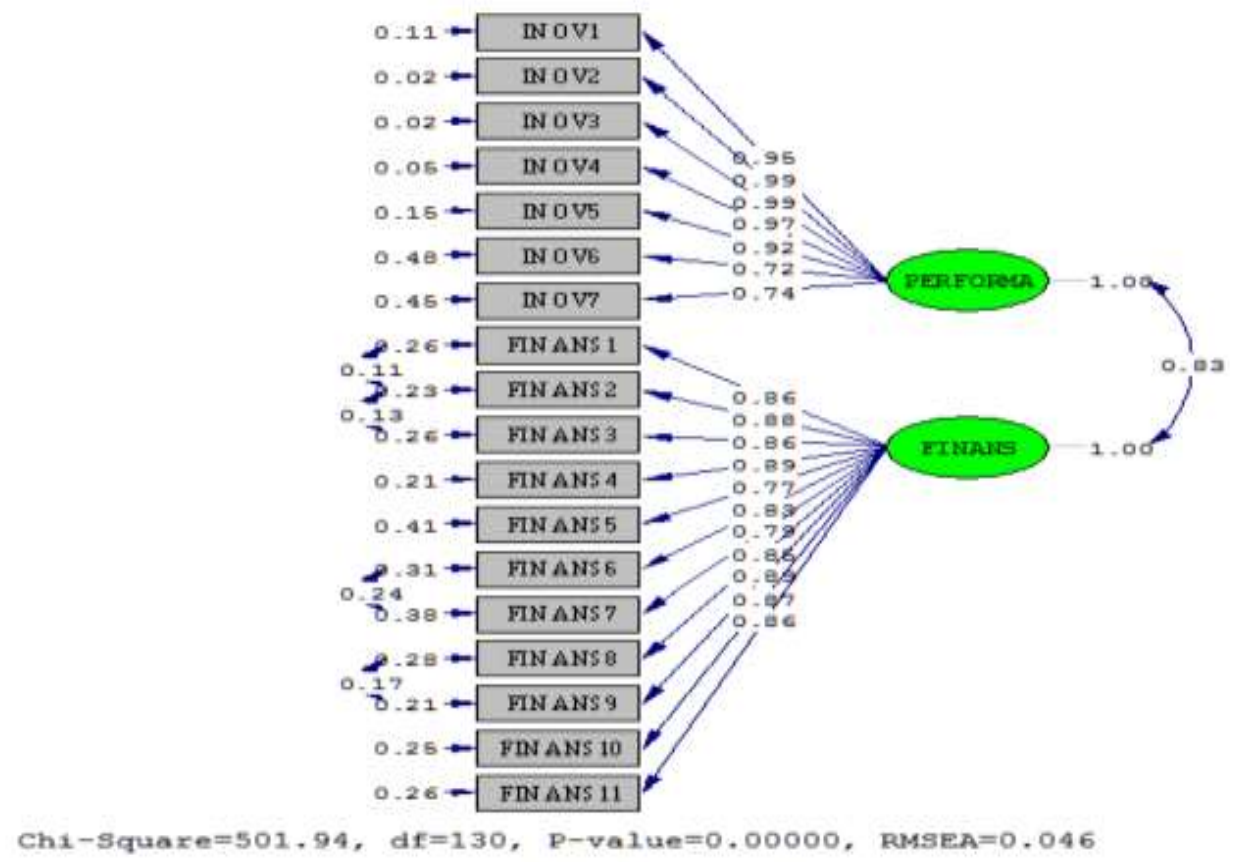

Şekil 2. İnovatif Performans Ölçeğine İlişkin DFA Analizi Sonuçları

Tablo 20. İnovatif Performans Ölçeğine Ait Ölçün Modelleri Sonucu

\begin{tabular}{lccc}
\hline Faktör/Madde & Standartlaştırılmış Yükler & t-değeri & $\mathrm{R}^{2}$ \\
\hline Inovatif Performans Ölçümü & & & \\
\hline INOV1 & 0,95 & 14,71 & 0,87 \\
\hline INOV2 & 0,99 & 16,01 & 0,94 \\
\hline INOV3 & 0,99 & 16,05 & 0,83 \\
\hline INOV4 & 0,97 & 15,53 & 0,61 \\
\hline INOV5 & 0,92 & 14,00 & 0,47 \\
\hline INOV6 & 0,72 & 9,64 & 0,83 \\
\hline INOV7 & 0,74 & 10,11 & 0,88 \\
\hline Pazar Ürünlerinin Finansal Performansı & & & 12,37 \\
\hline FINANS1 & 0,86 & & 0,74 \\
\hline
\end{tabular}




\begin{tabular}{lccc}
\hline FINANS2 & 0,88 & 12,87 & 0,77 \\
\hline FINANS3 & 0,86 & 12,41 & 0,74 \\
\hline FINANS4 & 0,89 & 13,06 & 0,79 \\
\hline FINANS5 & 0,77 & 10,42 & 0,59 \\
\hline FINANS6 & 0,83 & 11,8 & 0,69 \\
\hline FINANS7 & 0,79 & 10,8 & 0,62 \\
\hline FINANS8 & 0,85 & 12,2 & 0,72 \\
\hline FINANS9 & 0,89 & 13,05 & 0,79 \\
\hline FINANS10 & 0,87 & 12,63 & 0,76 \\
\hline FINANS11 & 0,86 & 12,37 & 0,74 \\
\hline
\end{tabular}

İnovatif performans ölçeğine ait DFA analizi yapılırken ölçeğin alt boyutları PERFORMA= İnovatif Performans Ölçümü, FINANS= Pazar Ürünlerinin Finansal Performans şeklinde isimlendirilmiştir.

İnovatif performans alt boyutlarından inovaktif performans ölçümünde 0,99'luk katsayı ile INOV2 " Mevcut ürün portföyünde yeni ürün yüzdesi " maddesi ve INOV3 "Yeni ürün ve hizmet projelerinin sayısı" maddesinin en etkili değişken olarak belirlenirken, Pazar ürünlerinin finansal performansı boyutu üzerinde 0,89'luk katsayı FINANS4 "Üretim ve teslim hızı" değişkeni ve FINANS9 "Aktif kârlılığı (kar / toplam aktifler) " maddeleri en etkili değişken olduğu belirlenmiştir.

Tablo 21. İnovatif Performans Ölçeği Alt Boyutlarına Ait Ölçüm Sonucu İlişki Değerleri

\begin{tabular}{lcc}
\hline & İnovatif Performans Ölçümü & Pazar Ürünlerinin Finansal Performansı \\
\hline İnovatif Performans Ölçümü & 1 & \\
\hline $\begin{array}{l}\text { Pazar Ürünlerinin Finansal } \\
\text { Performansı }\end{array}$ & $0,83^{*}$ & 1 \\
\hline * $<0.05$ & & \\
\hline
\end{tabular}

Tablo 21 incelendiğinde inovatif performans ölçümü ile Pazar ürünlerinin finansal performans arasındaki 0,83 'lük bir ilişkinin olduğu belirlenmiștir $(p<0.05)$. İnovatif performans ölücümün de artış olduğunda, Pazar ürünlerinin finansal performansında pozitif yönde kuvetli bir artış olacağı belirlenmiştir. $(\mathrm{p}<0.05, \mathrm{r}=0,830)$
Çalışmanın uygulama kısmında kurulan DFA'lara ait uyum kriterlerinin yer aldığı Tablo 30 incelendiğinde İnovasyon performansa ilişkin DFA analizi için uyum kriterlerin geneli için kabul edilebilir uyum sınırlar arasında yer aldığını söylemek mümkündür. Bu kriterler dışında $\chi 2(130)=501,94$; $\chi 2 / s d=3,86<5$ değeri de model uygunluğunun belirlenmesinde kullanılan diğger bir istatistik olup, modelin istatistiki açıdan uygun olduğunun diğer bir göstergesidir.

Tablo 22. Kurulan İnovatif Performansa Ait DFA Modeli İçin Uyum Kriterlerine Ait Değerler.

\begin{tabular}{cccc}
\hline $\begin{array}{c}\text { Uyum } \\
\text { Kriterleri }\end{array}$ & Mükemmel Uyum & Kabul Edilebilir Uyum & $\begin{array}{c}\text { Geliştirilen Ölçeğe Ait } \\
\text { Değerler }\end{array}$ \\
\hline$\chi 2 / s d$ & $\leq 3$ & $\leq 5$ & 3,86 \\
\hline RMSEA & $0<\mathrm{RMSEA}<0.05$ & $0.05 \leq \mathrm{RMSEA} \leq 0.10$ & 0,046 \\
\hline SRMR & $0 \leq \mathrm{SRMR}<0.05$ & $0.05 \leq \mathrm{SRMR} \leq 0.10$ & 0,047 \\
\hline $\mathrm{NFI}$ & $0.95 \leq \mathrm{NFI} \leq 1$ & $0.90 \leq \mathrm{NFI} \leq 0.95$ & 0,950 \\
\hline $\mathrm{NNFI}$ & $0.95 \leq \mathrm{NNFI} \leq 1$ & $0.90 \leq \mathrm{NNFI} \leq 0.95$ & 0,960 \\
\hline $\mathrm{CFI}$ & $0.95 \leq \mathrm{CFI} \leq 1$ & $0.90 \leq \mathrm{CFI} \leq 0.95$ & 0,970 \\
\hline GFI & $0.95 \leq \mathrm{GFI} \leq 1$ & $0.90 \leq \mathrm{GFI} \leq 0.95$ & 0,920 \\
\hline IFI & $0.95 \leq \mathrm{CFI} \leq 1$ & $0.90 \leq \mathrm{IFI} \leq 0.95$ & 0,970 \\
\hline RFI & $0.95 \leq \mathrm{RFI} \leq 1$ & $0.90 \leq \mathrm{RFI} \leq 0.95$ & 0,950 \\
\hline AGFI & $0.90 \leq \mathrm{AGFI} \leq 1$ & $0.85 \leq \mathrm{AGFI} \leq 0.90$ & 0,920 \\
\hline
\end{tabular}

Kaynak: (Schermelleh-Engel vd., 2003).

Tablo 22 incelendiğinde, inovasyon ölçeğine ait $\chi 2 / s d$, RMSEA, SRMR, NFI, NNFI, GFI, AGFI, IFI, RFI değerlerin kabul edilebilir uyum kriterleri içerisinde olduğu belirlenmiştir.

\subsection{Araştırma Modeli Ve Hipotezler}

İnovasyonun firma performansı üzerine etkisinin belirlenmesi için kurulan yapısal eşitlik modellemesine ait 
sonuçlar Şekil 3 ve Tablo 23'de verilmiştir. İnovasyon ölçümünü belirleyen değişkenlerin firma performansı üzerindeki etkisini gözlemlemek için tasarlanan alternatif araştırma hipotezleri aşağıdaki gibi oluşturulmuştur.

- $\quad H_{1}$ : Ürün İnovasyonu firma performansı üzerinde pozitif etkiye sahiptir.

- H2: Süreç İnovasyonu firma performansı üzerinde pozitif etkiye sahiptir.
- H3: Pazarlama İnovasyonu firma performans1 üzerinde pozitif etkiye sahiptir.

- H4: Organizasyonel İnovasyon firma performans1 üzerinde pozitif etkiye sahiptir.

Şekil 3'de kurulan model için, Tablo 23'de görüleceği üzere inovasyon ölçümü alt boyutlarından, pazarlama inovasyon ölçümleri ile organizasyonel inovasyon ölçümlerinin firma performansı üzerinde etkisine ait kurulan hipotezler istatistiksel açıdan \%95 güvenirlilikle anlamlı bulunmuştur.

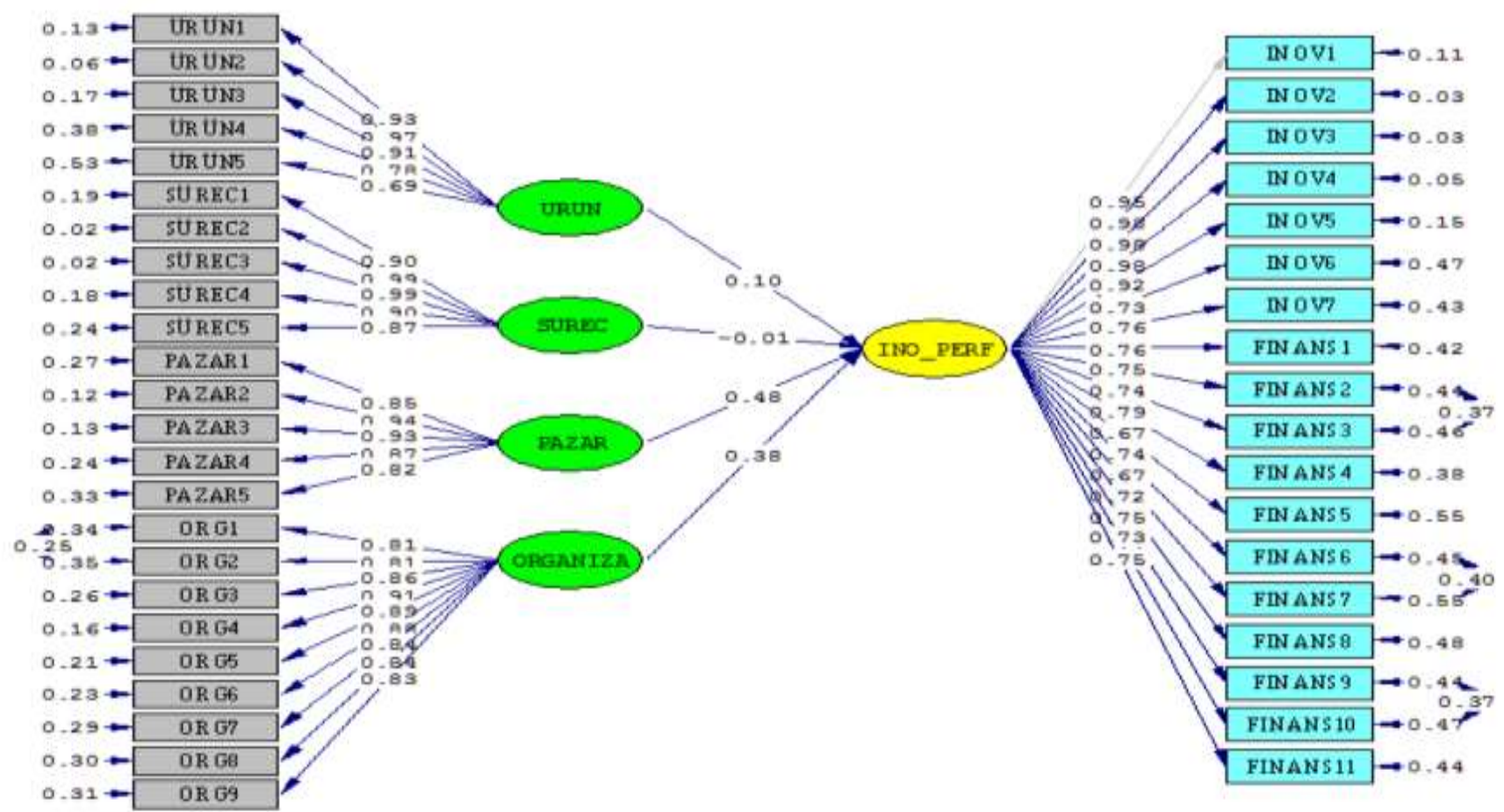

Ch1-square $=3062.76, d f=B 05, P-v a 1 u e=0.00000$, RaseA $=0.045$

Şekil 3. Hipoteze Ait Yem Modeli Sonucu

Tablo 23. Kurulan YEM Modeline Ait Uyum Kriterlerine Ait Değerler

\begin{tabular}{cccc}
$\begin{array}{c}\text { Uyum } \\
\text { Kriterleri }\end{array}$ & Mükemmel Uyum & Kabul Edilebilir Uyum & $\begin{array}{c}\text { Geliştirilen Ölçeğe Ait } \\
\text { Değerler }\end{array}$ \\
\hline$\chi 2 / s d$ & $\leq 3$ & $\leq 5$ & 3,800 \\
\hline RMSEA & $0<\mathrm{RMSEA}<0.05$ & $0.05 \leq \mathrm{RMSEA} \leq 0.10$ & 0,045 \\
\hline SRMR & $0 \leq \mathrm{SRMR}<0.05$ & $0.05 \leq \mathrm{SRMR} \leq 0.10$ & 0,095 \\
\hline NFI & $0.95 \leq \mathrm{NFI} \leq 1$ & $0.90 \leq \mathrm{NFI} \leq 0.95$ & 0,940 \\
\hline NNFI & $0.95 \leq \mathrm{NNFI} \leq 1$ & $0.90 \leq \mathrm{NNFI} \leq 0.95$ & 0,950 \\
\hline CFI & $0.95 \leq \mathrm{CFI} \leq 1$ & $0.90 \leq \mathrm{CFI} \leq 0.95$ & 0,950 \\
\hline GFI & $0.95 \leq \mathrm{GFI} \leq 1$ & $0.90 \leq \mathrm{GFI} \leq 0.95$ & 0,980 \\
\hline IFI & $0.95 \leq \mathrm{CFI} \leq 1$ & $0.90 \leq \mathrm{IFI} \leq 0.95$ & 0,930 \\
\hline RFI & $0.95 \leq \mathrm{RFI} \leq 1$ & $0.90 \leq \mathrm{RFI} \leq 0.95$ & 0,930 \\
\hline AGFI & $0.90 \leq \mathrm{AGFI} \leq 1$ & $0.85 \leq \mathrm{AGFI} \leq 0.90$ & \\
\hline
\end{tabular}

Kaynak: (Schermelleh-Engel vd., 2003). 
Tablo 23 incelendiğinde, kurulan modele ait $\chi 2 / s d, R M S E A$, SRMR, NFI, NNFI, GFI, AGFI, IFI, RFI değerlerin kabul edilebilir uyum kriterleri içerisinde olduğu belirlenmiş ve model uyum kriterlerine uygun olduğu için kabul edilebilir seviyede olduğu belirlenmiştir.

Tablo 24. Kurulan Modele Ait Standartlaştırılmış Parametre Tahminleri, T İstatistikleri Ve Hipotezler

\begin{tabular}{clcccc}
\hline Hipotezler & Yollar & \multicolumn{2}{c}{$\begin{array}{c}\text { Standartlaştırılmış } \\
\text { Parametre Tahminleri }\end{array}$} & $\boldsymbol{t}$ istatistiği & Sonuç \\
\hline $\mathbf{H}_{\mathbf{1}}$ & (URUN) $\rightarrow$ (INO_PERF) & 0,10 & $\mathbf{1 , 5 2}$ & Desteklenmedi \\
$\mathbf{H}_{\mathbf{2}}$ & (SUREC) $\rightarrow$ (INO_PERF) & $-0,01$ & $\mathbf{- 0 , 1 0}$ & Desteklenmedi \\
$\mathbf{H}_{\mathbf{3}}$ & (PAZAR) $\rightarrow$ (INO_PERF) & 0,48 & 4,20 & Desteklendi \\
$\mathbf{H}_{\mathbf{4}}$ & (ORGANIZA) $\rightarrow$ (INO_PERF) & 0,38 & 4,22 & Desteklendi \\
\hline
\end{tabular}

Tablo 24 incelendiğinde ürün inovasyon ölçümünün ve süreç inovasyon ölçümünün firma performansı üzerindeki etkisine ait kurulan hipotezler istatistiksel açıdan doğrulanmadığı belirlenmiştir. Pazar inovasyon ölçümü ve organizasyonel inovasyon ölçümünün firma performansı üzerindeki etkisine ait kurulan hipotezlerin istatistiksel açıdan doğrulandığı belirlenmiştir.Kurulan Yem modeline ait regresyon modeli sonucu aşağıda verilmiştir.

\section{Sonuç ve Öneriler}

Bu çalışmada Türk sermaye sisteminde faaliyet gösteren 182 imalatçı firmanın verileri kullanılarak inovasyonun firma performansı üzerine etkisi ortaya çıkarılmaya çalışıldı. Türk sermaye sisteminde faaliyet gösteren 182 imalatçı firmanın örneklemini kullanarak, inovasyonun firma performans1 üzerine etkisini rapor ederek başta firma yöneticileri olmak üzere, firmaların tüm paydaşlarına firma performans1inovasyon ilişkisi hakkında bilgi vermek hedeflendi.

İnovasyon ve firma performansı değişkenleri temel kabul edilerek birbirleri üzerindeki ilişkileri belirlenen teorik model vasıtasıyla ampirik olarak testi yapılmıştır. Çalışma sadece inovasyonun farklı firma performanslarını nasıl etkilediğini açıklamakla kalmamakta, aynı zamanda inovasyon performansının, inovasyon türleri ve performans yönleri arasında bir aracı rol oynadığını da göstermektedir.

Bulgular, imalat sanayinde faaliyet gösteren firmalarda gerçekleştirilen inovasyonların, firma performansı üzerinde olumlu ve anlamlı etkileri olduğunu desteklemektedir. İnovasyon ölçeğindeki inovasyon kalemlerinin kendi aralarında da etkileşimin olduğu yapılan analizlerle de ortaya konmuştur. Böylece, H3 ve H4 hipotezleri desteklenmektedir. Ancak, ürün inovasyonları ve inovatif firma performansı (H1) ile süreç inovasyonları ve inovatif firma performansı (H2) arasındaki ilişki, bu öğeler arasında anlamlı pozitif korelasyon olmasına rağmen, anlamlı bulunmamıștır. Bunun sebebi yol analizinde diğer tüm değişkenlerin kullanılmasından dolayı korelasyon analizi ile gözlemlenen değişkenlerle ilişkiler doğrudan olmayı birakmakta ve desteklenmeyecek olan hipotezleri yönlendiren bir aracılık yapısına dönüşmektedir. Hatta anlamlı bulunmayan hipotezler tek tek ele alındığında hipotezin kabul edilebilir sınırlara geçtiği gözlenmektedir. Öte yandan, firma verileri dikkate alındığında, inovatif firmaların daha yüksek pazar payı, toplam satıs ve ihracat
Firma Performans1 $=0,48 *$ Pazar inovasyon ölçümü $+0,38^{*}$ organizasyonel inovasyon ölçümü

Kurulan model incelendiğinde, pazarlama inovasyon ölçümünde bir birimlik artışın firma performansına pozitif yönde 0,48 'lik bir etkisi olacağı, organizasyonel inovasyon ölçümündeki bir birimli artışın firma performansını pozitif yönde 0.38 'lik bir etkisi olacağı, belirlenmiştir.

hacmine sahip olduğu görülmektedir. Bu pazar ve finansal kriterler için, inovasyonun tüm bileşenlerinde anlamlı ve olumlu rol oynamaktadırlar.

Bu bulgular, çalışma için düşünülen kavramsal modeli teyit ederek, çeşitli yönetimsel çıkarımlar sunmaktadır. Birincisi, şirketlerin yöneticileri, sürdürülebilir rekabet gücüne ulaşmak için önemli araçlar olduklarından, yeniliklere daha fazla önem vermelidir. Geliştirilmiş inovatif performans, yeniliklerin uygulanması derecesine bağlıdır. İnovasyon yeteneklerini geliştirmek için kaynaklara sahip olan firmalar, yüksek düzeyde inovasyon faaliyetlerini teşvik edip uygularlarsa, üretim ve pazar performanslarında daha önemli bir iyileşme bekleyebilirler. Satış, ihracat ve pazar payı gibi piyasa performans göstergelerinin, gerçekleştirilen inovasyon türleriyle desteklendiği de görülmektedir.

Tüm inovasyon tiplerinin birini diğerinden ayırmadan firma performansiyla ile mükemmel denebilecek uyum değerlerinin yakalanması firmalara adeta mesaj niteliğindedir. $\mathrm{Bu}$ nedenlerle, yöneticiler yenilikçi yeteneklere daha fazla yatırım yapmalı ve her türden yeniliği tanıtmak için yeni girişimleri desteklemelidir. Bulgular, inovasyon stratejisinin, firma performansının önemli bir temel itici gücü olduğu gerçeğini desteklemektedir ve iş hayatının ayrılmaz bir parçası olarak geliştirilmeli ve yürütülmelidir. Yöneticiler, operasyonel performanslarını artırmak için yenilikleri tanımalı ve yönetmelidir. İnovasyonların doğasını tam olarak anlayabilmek, firmaların pazar, üretim ve teknoloji stratejilerini önceliklendirmelerine yardımcı olacak ve uygun olan bir sonraki eylem planına ön ayak olacaktır.

Araştırma neticeleri referans alınarak, çalışmanın bulguları şöyle ifade edilebilir:

- Rekabetin vazgeçilmez doğası iyi kavranılmalıdır. Bu da firmaların bilgiyi en büyük güç kabul ederek, çalışanların eğitimlerini, gelişimlerini inovasyon odaklı bir yönetim 
anlayışıyla sürdürmek hususunda gereken özen gösterilmelidir.

- Başarı değerlendirme sistemi yeniden düzenlenmelidir. Firmaya katkı sunan çalışanlar tek düze satış hacminde yakaladıkları artış endeksli bir prim anlayışı revize etmelidir. Fikir geliştiren, yenilik üretip bunu ticarileştiren, paylaşımcılık ruhuyla hareket eden gibi özelliklere haiz çalışanlar, ödüllendirme mekanizmasında ve firma kariyer basamakları belirlenirken önemli artılar kazandıran hususlar olarak belirlenmelidir.

- Rekabette bilgiye önce ulaşma, rekabetin neden olduğu birçok tahribata karşı kalkan görevi görmektedir. Bilgiye ulaşmada yaşanan olumsuzluklar doğru ve etkin belirlenerek bu olumsuzlukların giderilmesi sağlanmalıdır.

- Çalışanların temininde insan kaynakları departmanı yenilikçi düşünen, paylaşımcı ruha sahip, inovasyon odaklı çalışama anlayışıyla bütünleşmiş bireyler belirlenen doğru kıstaslarla firmaya kazandırılmalıdır. Burada sadece başvuran kişilerin mezuniyet derecesi, bildiği dil sayısı gibi genel kriterler çerçevesinde yapılan değerlendirilmelerin uzun vadede inovasyon iklimli bir kültürün oluşmasında bir zaman kaybı yaşatacağı göz ardı edilmemelidir.

- Potansiyel yaratıcı gücün, yeni fikirlerin, kolektif aklın, paylaşımcı ve katılımcı bir yapının ortaya çıkabilmesi için katı hiyerarşi ve merkezilikten uzak esnek bir örgüt yapısı yaratılmalıdir.

- Ar-Ge firmaların olmazsa olmazı kabul edilmelidir. Bu sayede bu departmana doğrudan veya dolaylı hizmeti bulunan tüm taraflara yeterince finansman sağlanmalıdır. Çalışanlar başta olmak üzere kaynak dağılımı sağlanırken Ar-Ge kültürünün tüm firmaya yayılması sağlanmalıdır. İhtiyaç duyulan fiziki altyapı, zaman gibi ihtiyaç duyulan ortam sağlanmalıdır.

• Ödül ve ceza sistemi yazılırken risk faktörünün pozisyonu iyi konumlanmalıdır. Her inovatif çalışmanın başarıyla sonuçlanmayacağı çalışanlara aktarılmalı, sonucunda motivasyon kırıcı yaptırımların olmayacağı özellikle vurgulanmalıdır. Firmanın yenilikçi düşünce formunu sekteye uğratacak faaliyetlerden kaçınılmadır.

Bu hususlar dikkate alınmadığ kırıc1, katma değer oluşumunda öncü, rekabet savar özellikleri bünyesinde barındıran büyük bir güçten mahrum olunacak ve performans düzeyleri olumsuz etkilenerek, rekabette arzu edilen avantajlı durumdan uzaklaşılarak, sınırsız kabul edilen firma ömürleri son bulacaktır.

Bütün bilimsel araştırmaların tabiatında olduğu gibi bu araştırmanın da birtakım kısıtları vardır. Bu çalışmadaki ana kısıtlayıcısı, alan araştırmasında Türk sermaye sisteminin kalbi olan Borsa İstanbul'da kayıtlı olan imalat sanayiinde faaliyetlerini sürdüren 182 firmadır. $\mathrm{Bu}$ bağlamda, yaptığımız değerlendirmeler, yorumlar sadece bu ölçekte anlamlı ve geçerli olacaktır. Bu çalışma Borsa İstanbul'da faaliyet gösteren tüm firmalar üzerinde çalışılarak elbette ki daha kapsamlı, sanayi ve sektör bazlı sonuçlar elde edilebilecektir. Bu şekilde bütüncül olarak ele alınabileceği gibi esasında daha spesifik olarak; sektörel ve bölgesel bazlı çalışmalarla daha anlamlı sonuçlar elde edilebileceği gerçeği unutulmamalıdır.
$\mathrm{Bu}$ araștırma sonuçları, bundan sonra ele alınan farklı sektör ve sanayi kolunda faaliyet gösteren firmalar referans alınarak oluşturulacak örneklemlerle test edilebilecektir. Ulaşılan bulgular mukayese edilebilirliğe hizmet edeceğinden inovasyon ve firma performansı ilişkisini değerlendirebilmeye ilave katkı sunacaktır. Dolayısıyla firma yöneticileri başta olmak üzere tüm paydaşların ihtiyaç duyduğu bilgilerin ortaya çıkmasını sağlayacaktır.

Elde edilen sonuçlar ülke yöneticilerine de anlamlı mesajlar ulaştıracaktır. İnovatif düşüncenin desteklenerek firma performansının arttırılmasının; en nihayetinde ülke ekonomisine sağlayacağı faydalar göz önünde bulundurulmalıdır. Bunun içim inovasyon, Ar-Ge gibi performansa doğrudan etki eden faktörleri firma felsefesi haline dönüştüren firmalara çeşitli teşvik ortamı sunarak devlet eliyle daha çok özendirilmesi sağlanmalıdır.

Yatırımcılar hisse senedi alarak yatırım yapmak arzu ettiklerinde firmaların mali tablolarında Ar-Ge harcamalarını yıllar itibariyle karşılaştırarak artış trendini yakalayan firmaları tercih edebilirler. Esasında bu durumla daha çok inovatif firma iklimini yakalayan firmaların kar payı dağıtımının daha iyi düzeylerde olabileceği gerçeği unutulmamalıdır.

Alan yazın araştırmacılarına da birtakım öneriler sunulabilir:

- Bu çalışmanın özünde bulunmayan inovasyon ve firma performansı değişkenleri arasındaki ilişskilere etki edeceği düşünülen yeni değişkenler ilave edilerek farklı modeller üretip, testleri yapılabilir.

- İnovasyon ve firma performansı etkileşimi firma yaşı, firma büyüklüğü gibi parametreler odağında karşılaştırmalı analize tabi tutulabilir.

- Firmaların yönetim anlayışı ile inovasyon - performans etki düzeyini gözlemleyecek çalışmalar yapılabilir.

\section{Kaynakça}

Arıkan, R. (2000). Araştırma Teknikleri ve Rapor Yazma (3). Ankara: Gazi Kitabevi.

Atalay, M., Anafarta, N., ve Sarvan, F. (2013). The Relationship between Innovation and Firm Performance: An Empirical Evidence from Turkish Automotive Supplier Industry. Procedia - Social and Behavioral Sciences, 75(Supplement C), 226-235.

Biçkes, D. M. (2011). Örgütsel Öğrenme, İnovasyon ve Firma Performansı Arasındaki İlişkiler : İnovasyonun Aracılık Etkisine Yönelik Büyük Ölçekli İşletmelerde Bir Araştırma. Yayımlanmamış Doktora Tezi, Erciyes Üniversitesi Sosyal Bilimler Enstitüsü, Kayseri.

Cavusgil, T., Roger, C., ve Yushan, Z. (2003). Tacit Knowledge Transfer and Firm Innovation Capability. Journal of Business \& Industrial Marketing, 18(1), 6-21.

Chen, E., Ho, K. K.-L. (2002). Demystifying Innovation. Perspectives on Business Innovation (8), 46-52. 
Chung, K. H., Megginson, L. C. (1981). Organizational Behavior: Developing Managerial Skills: Harper \& Row, 506.

Damanpour, F. (1992). Organizational Size and Innovation. Organization Studies, 13(3), 375-402.

Elçi, Ş. (2006). İnovasyon : Kalkınma ve Rekabetin Anahtarı (2). Ankara: Nova Basın Yayın, 1.

Eren, M. Ş., Yücel, R., ve Eren, S. S. (2010). Firma Performansına Etkileri Kapsamında Çevresel Olumsuzluk, Pazar Dinamizmi, Müşteri Odaklılık ve Yenilikçilik Arasındaki İlişkilerin İncelenmesi. Journal Of Yaşar University, 18(5), 3102-3116.

Freeman, C., Soete, L., ve Routledge. (1997). The Economics of Industrial Innovation: Routledge, 232.

Grawe, S. J., Chen, H., ve Daugherty, P. J. (2009). The Relationship Between Strategic Orientation, Service Innovation, and Performance. International Journal of Physical Distribution \& Logistics Management, 39(4), 282-300.

Green, K. W., Inman, R. A. (2007). The Impact of JIT-IISelling on Organizational Performance. Industrial Management \& Data Systems, 107(7), 1018-1035.

Gunday, G., Ulusoy, G., Kılıç, K., ve Alpkan, L. (2011). Effects of Innovation Types on Firm Performance. International Journal of Production Economics, 133(2), 662-676.

Gürbüz, S., Şahin, F. (2016). Sosyal Bilimlerde Araştırma Yöntemleri Felsefe - Yöntem - Analiz. Ankara: SeçkinSosyal Bilimler.

Hart, S., Banbury, C. (1994). How Strategy-Making Processes Can Make a Difference. Strategic management journal, 15(4), 251-269.

Helvacı, M. A. (2002). Performans Yönetimi Sürecinde Performans Değerlendirmenin Önemi. Ankara Üniversitesi Eğitim Bilimleri Fakültesi Dergisi, 35(1-2), 155-169.
Matzler, K., Schwarz, E., Deutinger, N., ve Harms, R. (2008). The Relationship Between Transformational Leadership, Product Innovation and Performancein SMEs. Journal of Small Business \& Entrepreneurship, 21(2), 139-151.

Nohria, N., Gulati, R. (1996). Is Slack Good or Bad for Innovation? The Academy of Management Journal, 39(5), 1245-1264.

OECD. (2005). Oslo Kilavuzu : Yenilik Verilerinin Toplanması ve Yorumlanması İçin İlkeler (3). Paris: OECD, 21.

Schumpeter, J. A. (1983). The Theory of Economic Development. (Ç. R. Opie). Cambridge: MA: Harvard (eserin orijinali 1934' de yayımland1), 18-20.

Serper, Ö., Aytaç, M. (2000). Örnekleme (2). Bursa: Ezgi Kitapevi.

Shergill, G. S., Nargundkar, R. (2005). Market Orientation, Marketing Innovation as Performance Drivers: Extending The Paradigm. Journal of Global Marketing, 19(1), 27-47.

Sutherland, D., Hartmann, J., ve Seidel, M. (2002). From Roadmap To Roadway: Managing Innovation At BMW. Perspectives on Business Innovation(8), 33-38.

TDK. (1969). Türkçe Sözlük (Genişletilmiş Baskı). Ankara: TDK, 324-925.

Wong, S.-Y., Chin, K.-S. (2007). Organizational innovation management: An organization-wide perspective. Industrial Management \& Data Systems, 107(9), 12901315.

Yazıcıoğlu, Y., Erdoğan, S. (2014). SPSS Uygulamalı Bilimsel Araştırma Yöntemleri (4). Ankara: Detay Yayıncılık.

Zehir, C., Özşahin, M. (2007). Stratejik Karar Verme Hızını Etkileyen Örgütsel, Çevresel Faktörler ve Firma Performansı İlişkisi: İmalat Sektöründe Bir Saha Çalışması. İktisadi ve İdari Bilimler Fakültesi Dergisi, 9(1), 1-21. 